\title{
Assessment of the Impact of PV-Systems for Sustainable Agriculture and Rural Development: The Case of Wolaita Zone, Southern Ethiopia
}

\author{
Desalegn Jara Godibo \\ Wolaita Sodo University, College of Natural and Computational science, \\ Department of Physics, Wolaita Sodo, Ethiopia, Po, box 138 Ethiopia
}

\begin{abstract}
Solar photovoltaic (PV) systems have shown their potential in rural electrification projects around the Wolaita Zone, especially concerning Solar Home Systems (SHS). With continuing price decreases of PV systems, other applications are becoming economically attractive and growing experience is gained with the use of PV in such areas as social and communal services, agriculture and other productive activities, which can have a significant impact on rural development. There is still a lack of information, however, on the potential and limitations of such PV applications. The main objective of this study is, therefore, to contribute to a better understanding of the potential impact of PV systems on sustainable agriculture and rural development (SARD), especially concerning income-generating activities in Wolaita Zone. In addition, to identify the potential contribution of PV to rural development in order to gain further financial and political commitment for PV projects and programs and to design appropriate PV projects to study area. The preparation of the present study represents Solar photovoltaic systems, through their flexibility in use, offer unique chances for the energy sector to provide "packages" of energy services to remote rural areas such as for rural health care, education, communication, agriculture, lighting and water supply. It is hoped that this document contributes to the generation of ideas and discussions among the different institutions involved in providing these services to rural areas in Wolaita Zone to overcome affordability (cost of the technology relative to farmer income levels), awareness (knowledge about the technology), accessibility (options for obtaining the technology), and lack of customization (capacity to match farmer needs with technological solutions).
\end{abstract}

Keywords: solar energy; photovoltaic; rural development; income generation; agriculture

DOI: $10.7176 / \mathrm{JETP} / 11-4-01$

Publication date:July $31^{\text {st }} 2021$

\section{Introduction}

Most of the remote rural areas of Ethiopia are not yet electrified. Electrifying these remote areas by extending grid system to these rural communities is difficult and costly. As the current international trend in rural electrification is to utilize renewable energy resources; solar, wind, biomass, and micro hydro power systems can be seen as alternatives. Among these, solar energy system is thought to be ideal solution for rural electrification due to abundant solar radiation availability nearby the rural community in Ethiopia $[1,2,4]$.

Ethiopia lies in the sunny belt between northern latitudes of $3^{0}$ and $15^{\circ}$, and thus the potential benefits of renewable energy resources such as solar energy system can be considerable. As mentioned in [9] the total annual solar radiation reaching the territory is of the order of over 200 million tone oil equivalent (toe) per year, over thirteen fold the total annual energy consumption in the country. In terms of geographical distribution, solar radiation that reaches the surface increases as one travels from west to east: the insolation period is approximately 2200 hours of bright sunshine per year in the west increasing to over 3300 hours per year in the eastern semiarid regions [6].

So far, these vast renewable energy resources are not exploited sufficiently in the country, primarily due to the lack of scientific and methodological know-how as regards planning, site selection, and technical implementation. A further constraint prohibiting their utilization is that the real potential of these resources is not well-known, partly because of the lack of research emphasis in developing these technologies, and partly because of the insufficient resource data base [3].

The aim of this paper is to contribute to a better understanding of the potential impact and of the limitations of PV systems on sustainable agriculture and rural development, especially concerning income-generating activities of rural area of Wolaita Zone of the Ethiopian SNNPR State which not electrified via national grid system. The people in this village use kerosene for lamp, diesel for water pumping and grinding machines, fire wood for cooking and dry cells for radio and tape recorders. Desertification of the land is getting worse and worse due to deforestation and backward agriculture. Thus, in this research paper assessment of the impact of PV systems for sustainable agriculture and rural development for selected villages found in Wolaita Zone is analyzed. 


\subsection{Objectives of the study}

\subsubsection{General Objective}

The main objective of this study is to contribute to a better understanding of the potential impact and of the limitations of PV systems on sustainable agriculture and rural development, especially concerning incomegenerating activities in Wolaita Zone.

\subsubsection{Specific objectives}

$\checkmark$ To identify the (potential) contribution of PV systems to rural development in order to gain further financial and political commitment for PV projects and programs in Wolaita Zone.

$\checkmark$ To check the status of the different applications of PV system in terms of extent of use and replicability (in terms of technical potential and economic competitiveness) in Wolaita Zone.

$\checkmark$ To identify the major applications of PV systems at present - especially activities related to income generating activities in Wolaita Zone

$\checkmark$ To provide information based on this study to researchers and policy makers.

\section{Background}

Ethiopia is a landlocked country situated in the Horn of Africa with a population estimated at over $\mathbf{1 0 8}$ million by 2018 . Its annual population growth rate of $2.46 \%$ ranks it $28^{\text {th }}$ fastest growing of 229 countries in the world [7]. In terms of gross domestic product (GDP) per capita Ethiopia is rated $174^{\text {th }}$ of 179 and in terms of human development index it is rated $169^{\text {th }}$ of 177 [8]. These numbers indicate Ethiopia as one of the poorest countries in the world. More country specific data can be found elsewhere [9]. Most Ethiopians live in rural areas (84\%) and only $1 \%$ of those have access to electricity.

Nevertheless, solar irradiation is well above $2,000 \mathrm{kWh} / \mathrm{m}^{2} / \mathrm{y}$, ranging from $1,950-2,600 \mathrm{kWh} / \mathrm{m}^{2} / \mathrm{y}$, providing an excellent basis for PV (Figure 1). Due to its conditions, Ethiopia is an excellent example for most of the least developed countries in the Sunbelt; hence several results achieved for Ethiopia might be transferred to countries comprising more than 500 million people around the world.

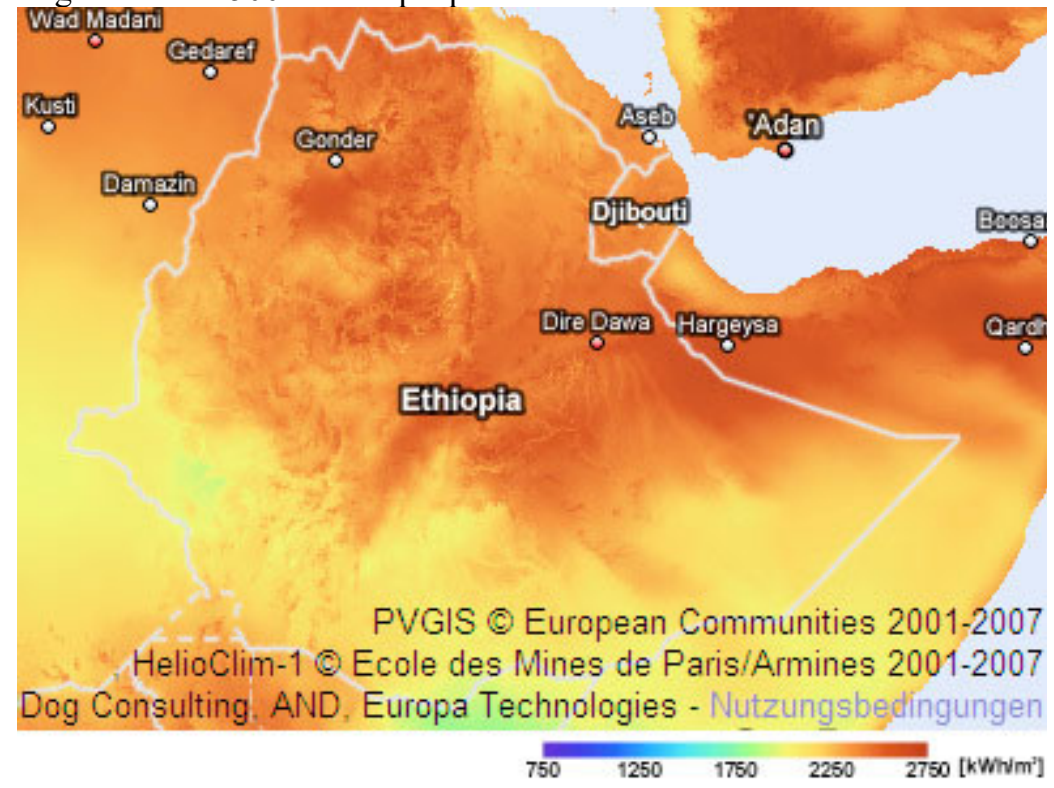

Figure 1: Global irradiation incident on optimally inclined equator-oriented PV modules in Ethiopia [10].

Currently Ethiopia generates its power from its vast hydro power potential and supplemented diesel power plants. $647 \mathrm{MW}$ or $89 \%$ of the installed grid connected capacity comes from hydro-electric power plants [11]. Economically feasible hydro-electric power potential would be up to $30 \mathrm{GW}$ [12]. Due to seasonal rainfalls the generation capacity significantly depends on the amount of rain water during the raining season. This results in power shedding during periods with low water levels. Such periods regularly force the Ethiopian Electricity Power Company (EEPCO) to cut off customers from power supply, even in the capital. Ethiopia has launched construction of several new hydroelectric power plants to prevent power shortages and meet the demand growth [11].

Ethiopia exhibits excellent prerequisites for a nearly $100 \%$ renewable energy supply. Superb hydro and solar resources offer the chance of renewable energy supply in an economically, ecologically and socially sustainable way. Such PV-hydro potentials have been already analyzed for Ethiopia [13] and might lead to utility-scale PV power plants [14]. These enormous renewable energy potentials might be connected to the DESERTEC plan in EU-MENA (Europe, the Middle East and North Africa) region [15] and further document the enormous energy 
supply potential of renewable energy sources.

Nevertheless, more than $80 \%$ of the Ethiopian population has no access to electricity, in particular in rural areas where more than $80 \%$ of the Ethiopians live. Overcoming this obstacle is a key for sustainable rural development.

\subsection{Economics of Off-Grid PV in Ethiopia}

Like everywhere in the world, consumers in Ethiopia have a need for such as light, communication (e.g. radio, $\mathrm{TV}$, cell phone) or mechanical energy (e.g. cooling, water pumping) but not electricity as an end in itself. In Ethiopia conventional rural energy usage is based on kerosene lamps for light and dry cell batteries for radios and tape recorders. Electric light is more easy and comfortable to handle, brighter, less expensive, cleaner and much safer than kerosene lamps.

\subsection{Small Off-Grid PV Solar Home Systems vs Conventional Energy Use}

Typical off-grid PV solar home systems (SHS) in Ethiopia consist of a 10Wp PV module, charge and remote controller, $18 \mathrm{Ah}$ gel lead acid battery, two $50 \mathrm{~lm} / \mathrm{W}$ LED lamps and one plug for a radio or tape recorder. Commonly two kerosene lamps are used by one family plus optionally one radio or tape recorder powered by dry cell batteries.

A simple financial tool for comparing alternative options is the calculation of payback periods [16]. Knowing all cash flows for investment, spare parts, service, financing cost and available budgets for energy needs, one can derive the payback period in which the investment pays off. If the lifetime of an investment is longer than the payback period, a financial benefit will be generated.

All necessary data are available in local currency, therefore the calculation is performed in Ethiopian Birr (ETB), as of March 2009, currency exchange rate was set to 14 ETB/€. Major assumptions are for the average energy budget of an Ethiopian family, cost of the SHS and its components, which have to be exchanged in regular intervals: complete $10 \mathrm{Wp}$ PV system (3,200 ETB), fuel cost for one kerosene lamp (45 ETB/month), dry cell batteries for one radio (24 ETB/month), dry cell batteries for one tape recorder (48 ETB/month), new PV battery (440 ETB/every 4 years), new charge and remote controller (600 ETB/every 10 years), 4 new LED lamps (400 ETB/every 7 years), inflation $10 \%$ p.a. and credit cost $3 \%$ p.a. over inflation rate [17].

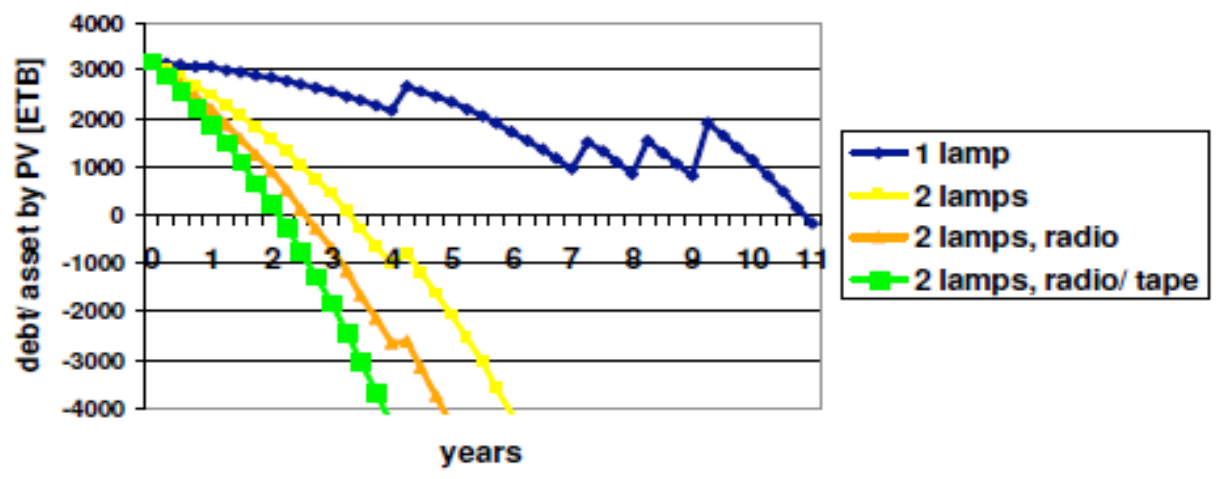

Figure 2: Payback period of small off-grid PV systems in Ethiopia. A today's $10 \mathrm{Wp} \mathrm{PV} \mathrm{system} \mathrm{is} \mathrm{compared} \mathrm{to}$ conventional energy consumption in rural areas. Replacement needs for battery, LED lamp and charge controller are the reason for the discontinuous shape of the graphs [17].

The payback period of a standard $10 \mathrm{Wp}$ SHS is between 2 to 4 years, depending on energy consumptions habits of the users. Families using two kerosene lamps reach break-even of their investment in a 10Wp SHS in about 3.5 years. After break-even there are only regular replacement costs of some components which add up to a significant monthly reduction of energy cost by about $80 \%$. This $80 \%$ cost reduction is equivalent to a present value [16] in the year of break-even of about 8,500 and 20,000 ETB for assumed system lifetimes of 10 and 20 years, respectively. Families with larger energy budgets, for the given example of two lamps and dry cell batteries for radio and tape recorder, reach break-even in 2.2 years, benefit from a $90 \%$ cost reduction of their energy budget in the year of break-even and achieve a present value in the year of break-even of about 15,500 and 32,000 ETB for assumed system lifetimes of 10 and 20 years, respectively. Notably, these present values approximately equal 9 and 18 times the GDP/capita, respectively. Saved energy spending can be used for increasing the standards of living, e.g. better energy supply, education, medical aid, improved houses and much more.

Financial benefit for SHS owners is obvious, in particular in respect to an expected system lifetime of 20 years. Profitability of rural off-grid SHS is considerably higher than on-grid PV installations in most developed 
countries [18]. A comparable metric would be the internal rate of return (IRR), which indicates the profitability of an investment [16]. Inflation corrected IRR for on-grid PV installations are about 5-7\%, whereas IRR for the two lamps and the two lamps plus dry cell batteries case reaches 28 and 45\%, respectively. Main reasons for this remarkable economic outcome are: high energy prices for rural population, which correlate to world market prices for fossil fuels, and ineffective use of the energy.

\subsection{Off-Grid PV vs Diesel Generators}

Despite low income in Ethiopia the desire to use electricity is very strong and Ethiopians are willing to pay high prices for electricity. In the past rural electrification was primarily realized by simply installing one diesel generator per village and connecting the houses to it. With focus on oil price development new options like PV came to mind. To replace the existing model of electrification PV has to fulfill some requirements: the consumer wants electricity to be reliable, affordable and available when he needs it.

For PV this obviously can only be achieved by installing a storage system like a lead acid battery, which is commonly used throughout the world, a reliable technology and a cheap way to store small amounts of electricity with focus on costs. This configuration of the PV system can provide a reliable supply of electricity whenever there is demand.

The major question is whether PV is affordable for rural population in Ethiopia? For the case of a $10 \mathrm{Wp}$ SHS versus conventional energy use, the profitability calculation is shown in section 2.2. For the case of PV systems versus diesel generators [19], an appropriate financial tool for answering this question is the concept of levelized cost of electricity (LCOE) [16]. All cost categories, i.e. investment and capital cost, operation and maintenance and fuel cost, have to be put on an annual basis. LCOE are obtained by dividing annual costs by annual energy generation, this enables a direct comparison of alternatives in terms of cost per energy, in this section $€ / \mathrm{kWh}$.

Several assumptions have to be taken into account for the comparison. Major assumption is the supply of an entire village, i.e. a system size of at least $1 \mathrm{kWp}$. Costs for a low voltage distribution system are neglected, as it is required for both systems. Estimates for these costs are in the order of up to $0.60 € / \mathrm{kWh}$ for comparable energy consumption profiles [20]. In case of one single electricity user, e.g. for small businesses, no distribution network would be needed and the following cost estimates can be used. Assumptions for the PV system are: investment cost PV system excluding storage $4,000 € / \mathrm{k} \mathrm{Wp}$, investment cost storage system $250 € / \mathrm{kW}$ and 280 $€ / \mathrm{kWh}$, battery lifetime between $4-10$ years, 6 hours of average daily battery usage, maximum usage of battery capacity $70 \%$, weighted average cost of capital $6.4 \%$, ratio of direct PV electricity consumption to stored PV electricity consumption 1:1. Assumptions for diesel generator system are: investment cost $250 € / \mathrm{kW}$, annual operation and maintenance $35 € / \mathrm{kW}$, lifetime 6 years, load factor $50 \%$, energy conversion efficiency $33 \%$, weighted average cost of capital $6.4 \%$, fuel price diesel $0.89 \$ / 1$, currency exchange rate $1.4 \$ / €$, effective premium of diesel price in Ethiopia compared to world market price of crude oil by $100 \%$, increase of diesel fuel in rural areas far away from trade centers (distance to port factor, DtP) by $50 \%$ and energy density of diesel 10 $\mathrm{kWhth} / 1[21,22]$.

In combination of these facts it is easy to understand why diesel generators are such an interesting option at the first sight. The problem of this solution is that the major part of cost will come later during operation and make it complicated to run a diesel generator continuously.

In rural areas it is rather difficult to maintain a diesel generator because of the lack of essential spare parts and fuel availability or for maintenance reasons. As a result of this some villages own a generator, but it is out of operation and cannot supply reliable electricity. Another problem is the low voltage connection of the houses. In some cases the villagers cannot afford to connect their house to the central generator. Energy loss in such low voltage distribution networks and low power demand of end-users are significant and worsen the financial performance. Furthermore air and noise pollution of a diesel generator is not negligible.

PV systems combined with an appropriate electricity storage system can minimize the operation cost and need only minor maintenance due to the absence of moving parts. Provides that batteries and PV are properly recycled at the end of their lifetime, there will be no pollution and a further positive environmental effect will be generated by a shorter energy payback time of the entire system [23]. Such a system can provide electricity to the customer during the lifetime estimated to 25 years for PV and 4 - 10 years for lead acid batteries. Due to the modular characteristic, the system can be extended in case of growing electricity demand and according to needs of the users.

All these facts reveal PV as one of the most promising solutions for rural electrification. It is free of pollution and runs without fuel. But as the LCOE for diesel generators strongly depends on the oil price PV needs certain oil prices to be competitive.

LCOE of PV is independent on oil price variations, whereas LCOE of diesel generators escalates with rising oil prices. Due to the lack of proper infrastructure and supply the diesel price per liter in larger cities and trade centers cannot be applied in rural areas. An additional factor has to be added to quantify the transport costs and 
the trader margin, according to the aforementioned assumptions a conservative increase by about $50 \%$ is expected, as one can locally observe increases up to $70-100 \%$.

Generation cost of PV electricity is dependent on the specific system design, the quality of components and optimized operation modes. LCOE of PV without storage can be expected to be slightly below $0.25 € / \mathrm{kWh}$, which equals an effective crude oil price of $50 \$ / \mathrm{bbl}$. Off-grid PV solutions including battery storage of 4 and 10 years battery lifetime can achieve LCOE of about 0.37 and $0.55 € / \mathrm{kWh}$, which equals an effective crude oil price of 80 and $120 \$ / \mathrm{bbl}$, respectively. In 2008 the spike of crude oil prices was above $140 \$ / \mathrm{bbl}$. Historically high crude oil prices are very likely in the years to come due to the fact of globally declining oil reserves [24].

An analysis of these estimates shows a clear indication. Only during a short transition period a combination of PV and diesel generators seem to be economic, in particular a combination of existing diesel generators with new PV systems without storage. Whenever the sun is shining, solar power is used and costly fuel is saved. Batteries with optimized lifetime are essential for an early diesel-parity of stand-alone off-grid PV solutions. High battery lifetimes can be achieved by providing a closed system to the user, which prevents misbehavior like deep discharge and therefore increases lifetime. This means, in some regions and if other additional costs apply, PV is already competitive at current oil prices. Furthermore, there may be a significant upward potential in the favour of PV, due to increasing oil prices and further decreasing PV cost [18].

\subsection{Addressable Markets for Off-Grid PV in Ethiopia}

The last two paragraphs showed that small off-grid SHS are highly beneficial for rural population in Ethiopia and village power supply by diesel generators is no real alternative. Based on this insight, together with Ethiopian energy experts we derived a rough estimate of today's addressable market for SHS in Ethiopia (Table 1) [25]. A good overview on current market trends in Ethiopia and evaluations of local strategies can be found elsewhere [26, 27].

Typical off-grid PV home systems in Ethiopia consist of a $10 \mathrm{Wp}$ PV system. An estimate of Ethiopian PV experts led to PV system demand in power units of $2 \mathrm{Wp}$ for light for one house $4 \mathrm{~h} /$ day, $10 \mathrm{Wp}$ for light and music, $20 \mathrm{Wp}, 50 \mathrm{Wp}$ and $100 \mathrm{Wp}$ which is sufficient for a little cinema or a health station with refrigerators. This estimate is close to similar analyses of other Ethiopian experts [27] and is based on today's GDP/capita. Optimized PV systems are expected to be sold at a significantly lower price than today, including scaling effects in distribution channels in Ethiopia. These effects are known from other markets and are reflected in local prices $[28,29]$. Assumptions for the calculation below are: addressable rural households in Ethiopia (10 million), specific off-grid PV SHS price (150 ETB/Wp), currency exchange rate (14 ETB/€) and several years of market development. Markets for commercial off-grid and on-grid PV systems are not considered but would significantly increase the market potential.

Table 1: Ethiopian cumulated off-grid PV addressable markets for solar home systems [17].

\begin{tabular}{|l|l|l|l|l|l|}
\hline $\begin{array}{l}\text { PV Systems } \\
(\mathrm{Wp})\end{array}$ & $\begin{array}{l}\text { Distribution } \\
(\%)\end{array}$ & $\begin{array}{l}\text { Households } \\
(\mathrm{milo})\end{array}$ & \multirow{2}{*}{$\begin{array}{l}\text { PV Demand } \\
(\mathrm{MWp})\end{array}$} & \multicolumn{2}{l|}{ Market for optimized systems } \\
\hline 2 & $20 \%$ & 2 & 4 & {$[\mathrm{mETB}]$} & {$[\mathrm{m}]$} \\
\hline 10 & $20 \%$ & 2 & 20 & 600 & 43 \\
\hline 20 & $30 \%$ & 3 & 60 & 3,000 & 214 \\
\hline 50 & $20 \%$ & 2 & 100 & 9,000 & 643 \\
\hline 100 & $10 \%$ & 1 & 100 & 15,000 & 1,071 \\
\hline Total & $100 \%$ & 10 & 284 & 15,000 & 1,071 \\
\hline
\end{tabular}

Remarkably, nearly all Ethiopians in rural areas could have access to electricity and they could afford it. These estimates show that $70 \%$ of rural population would significantly improve their standards of living and effectively save money for energy needs if they had access to SHS in the power range of not more than $20 \mathrm{Wp}$. The market segments for SHS larger than $20 \mathrm{Wp}$ might offer an addressable volume of about 2,000 million $€$. As discussed in section 2.2 investments in SHS would pay off within 2 to 4 years and reduce energy budgets by 80 $90 \%$ after this payback period. Imagine a fast and nationwide diffusion of privately financed SHS, an enormous boost in private financial capabilities in rural areas can be expected. Rural villagers can decide which needs they may cover first, e.g. enlargement of their SHS, education, investments in their houses, medical aid, communication technologies and much more. Besides the Solar-Center dissemination strategy by Solar Energy Foundation, a solar enlightenment program for schools in Ethiopia could convince rural villagers how solar energy could improve their own lives. Similar programs were started in other countries [30].

\subsection{Solar Pump Irrigation in Ethiopia}

About 1.4 million farmers are engaged in small-scale irrigated agriculture in Ethiopia, 210,000 to 400,000 of who use motor pumps [31]. Mendes and Paglietti estimated the annual value of imported motor pumps in Ethiopia in 2012 to be USD 10 million, an important subset of the USD 70 million spent on imported irrigation equipment [32]. The authors predicted that this value could increase tenfold if Ethiopia achieves its 2020 targets 
for irrigated agriculture. Limited access to electricity is a key constraint to expanded irrigation: only $14 \%$ of the population is connected to the electricity grid due to poor grid coverage and the dispersed nature of settlements in rural areas $[32,33]$. The government recognizes that the Rural Electrification Fund - established in 2003 - has not managed to scale up off-grid solar energy technologies. The Carbon Development Initiative, administered by the Development Bank of Ethiopia (DBE) with the World Bank as trustee, includes new efforts in renewable energy. The government's strategy is to transition existing motor pump users to solar, while also introducing new solar pump irrigation to those not currently irrigating. Given the number of existing and potential pump users, the scope for expanding the solar pump market for irrigation appears significant.

The Clean Development Mechanism (CDM) program aims to extend the use of solar irrigation pumps to enhance farming productivity, while enabling savings from fuel costs for diesel irrigation pumps and offsetting carbon emissions [34]. At the same time, the program seeks to strengthen private sector involvement in renewable energy access, by assisting this sector to become instrumental in the widespread sales of householdand community-level renewable energy technologies. The Ministry of Agriculture has the task of developing financing models for households to purchase solar pumps for irrigation, and raising awareness about the opportunity to acquire solar pump technologies, possibly with private sector enterprise support. At the same time, the DBE is supposed to raise awareness among microfinance institutions (MFIs) about possibilities for acquiring financing to enable onward lending to households for solar technologies. This would require the MFIs to register with the DBE for loan management, and increase reporting to the government on loans to households for solar pump technologies. The initiative maintains key roles for the government and state enterprises, despite aims for private sector engagement.

To date, federal and regional state government institutions have driven the market for solar power in Ethiopia. Solar power is mainly used for rural electrification and, on a much smaller scale, for solar pumps to supply rural water and sanitation needs and water for irrigation. A number of public and donor institutions plan to provide support for solar pump irrigation projects in the coming years. For the $2016 / 2017$ budget year, the Rural Electrification Fund includes renewable energy interventions, including solar power (see Table 2). The anticipated cost of the plan for 2016/2017 is ETB 1.6 billion (or approximately USD 70,645,000). This is primarily for procurement and installation or distribution of solar home systems and solar lanterns, but there is a small line for solar pumps. Loans (66\%), grants $(33 \%)$ and the government budget $(1.2 \%)$ should finance the solar-related expenses. The strategy for implementation includes collaboration between technicians from solar companies, local microenterprises and finance institutions on loans to small and medium enterprises, manufacturers, suppliers and distributors.

Table2. Rural Electrification Fund, Growth and Transformation Plan II (GTP II) (2015-2020): Activity plan and budget for solar expansion [35].

\begin{tabular}{|l|l|l|l|l|l|l|}
\hline No. & \multicolumn{1}{|c|}{ Description } & \multicolumn{5}{c|}{ Quantity per year } \\
\cline { 3 - 7 } & & $2015 / 2016$ & $2016 / 2017$ & $2017 / 2018$ & $2018 / 2019$ & $2019 / 2020$ \\
\hline 1 & Solar lanterns & 400,000 & 500,000 & 700,000 & $1,000,000$ & $1,000,000$ \\
\hline 2 & Solar home systems & 50,000 & 50,000 & 100,000 & 100,000 & 100,000 \\
\hline 3 & Institutional PV systems & 500 & 500 & 800 & 800 & 1,000 \\
\hline 4 & Solar thermal & 500 & 750 & 1,000 & 1,250 & 1,250 \\
\hline 5 & Solar cookers & 200 & 400 & 500 & 1,000 & 1,500 \\
\hline 6 & Solar mini-grid and & 15 & 25 & 40 & 70 & 100 \\
\hline 7 & Solar water pump for Technical & 5 & 8 & 10 & 12 & 15 \\
\hline 8 & $\begin{array}{l}\text { Training } \\
\text { Vocational Education and Training } \\
\text { (TVET) graduates }\end{array}$ & & 300 & 300 & 300 & 400 \\
\hline 9 & Wind power water pumping & 20 & 40 & & & \\
\hline 10 & Micro hydropower development & 9 & 13 & 22 & 26 & 30 \\
\hline 11 & $\begin{array}{l}\text { Wind-powered electrification study } \\
\text { and development }\end{array}$ & 3 & 4 & 5 & 6 \\
\hline
\end{tabular}

As indicated in budget line 7 in Table 2, the government plans a small number of large-scale, solar pump irrigation projects to be implemented in three regional states: Afar, Amhara and Somali. According to interviews with stakeholders, the Somali Regional State is entering into an agreement with a state enterprise, the Metals and Engineering Corporation (METEC), to develop systems at Kulen (2,000 ha) and Harewe (2,000 ha). A similar agreement is being signed with the Afar Regional State to provide solar pumps for the Serdo (1,443 ha) and Sunata (2,000 ha) irrigation projects for smallholders. The Kobo Integrated Irrigation Development Project, which will use 20 solar pumps, is another planned large-scale solar irrigation project in Amhara Regional State. In addition, six irrigation dams are under construction in the Tigray Regional State, with plans to introduce a hybrid system of micro hydropower and solar power for domestic and irrigation purposes. The Fentale project In 
Oromia Regional State receives its water supply from the Awash River, mainly due to gravity, but large diesel pumps must supply the 2,000 ha of land not suitable for gravity-fed irrigation. The pilot initiative aims to supplement and then replace these pumps with a hybrid solar system. The Japanese government is funding the project and the manufacturing company Kyocera is providing technology and expertise. The Koga irrigation project is a large scheme whose discharge wells remain idle due to power shortages. Recently, a comparative advantage study of solar, diesel and hydropower electric pumps showed solar to be feasible. As a result, the Koga irrigation project office intends to purchase and install 20 large discharge solar pumps [36].

The Ministry of Water, Irrigation and Electricity (MoWIE) administers procurement and funding for irrigation projects, but regional water bureaus own the schemes. According to policy, regional states should cover the full cost of large-scale irrigation projects. However, interviews conducted suggest that farmers will be required to cover partial or full costs of some of the projects after they begin harvesting. Regional states have limited funds available for irrigation investments and lack the capacity to respond to demand, and lack sufficient expertise about solar pump irrigation systems to determine the type of system needed with technical specifications, cost, etc. Experts in the irrigation subsector clearly identified a general knowledge gap around solar-powered pumps. Engineers and planners have stated that they avoid addressing requests for solar pumps, fearing failure and rejection by decision makers and end users [36].

In brief, public and development sector actors believe there is huge scope for solar pumps, but the public sector is unable to meet the full demand for solar irrigation. Moving away from conventional donor-funded and publicly-funded development requires market-driven mechanisms to catalyze the scaling up of solar irrigation pumps. However, the private sector supply of solar pumps has not developed sufficiently to serve the potential market. Broadly, stakeholders observe a number of factors constraining private sector market expansion: affordability (cost of the technology relative to farmer income levels), awareness (knowledge about the technology), accessibility (options for obtaining the technology), and lack of customization (capacity to match farmer needs with technological solutions). Economically viable business models could offer direction for the private sector development of the solar pump market, and thereby contribute significantly to the growth of the solar pump-based irrigation sector. Innovative business models enable assessment of the likely yield from different approaches to taking the technology to market [37]. The current context points to the need for smart business models that do not require sustained donor input, but present opportunities for private, market chain actor investment that could lead to sustained benefits. This report uses a business model framework for mapping the suitability of solar energy-based irrigation pumps in the case of Ethiopia.

\section{Material and Methodology}

\subsection{Description of the Study area}

The study zone, Wolaita Zone is located in southern Ethiopia and is bound by geographical coordinates $6.4^{\circ}$ and $7.1^{\circ} \mathrm{N}$ latitudes and $37.4^{\circ}$ and $38.2^{\circ}$ E longitudes. It has a total area of $4400 \mathrm{~km}^{2}$. Its altitude ranges from 1,200 to $2,950 \mathrm{~m}$ above sea level. It is located at a distance of $380 \mathrm{~km}$ along the main road that stretches north to south from Addis Ababa and is also connected with the South Nation National Regional State capital, Hawassa, 160 kms, Via Shashemane - Wolaita road to the south (See figure 3).

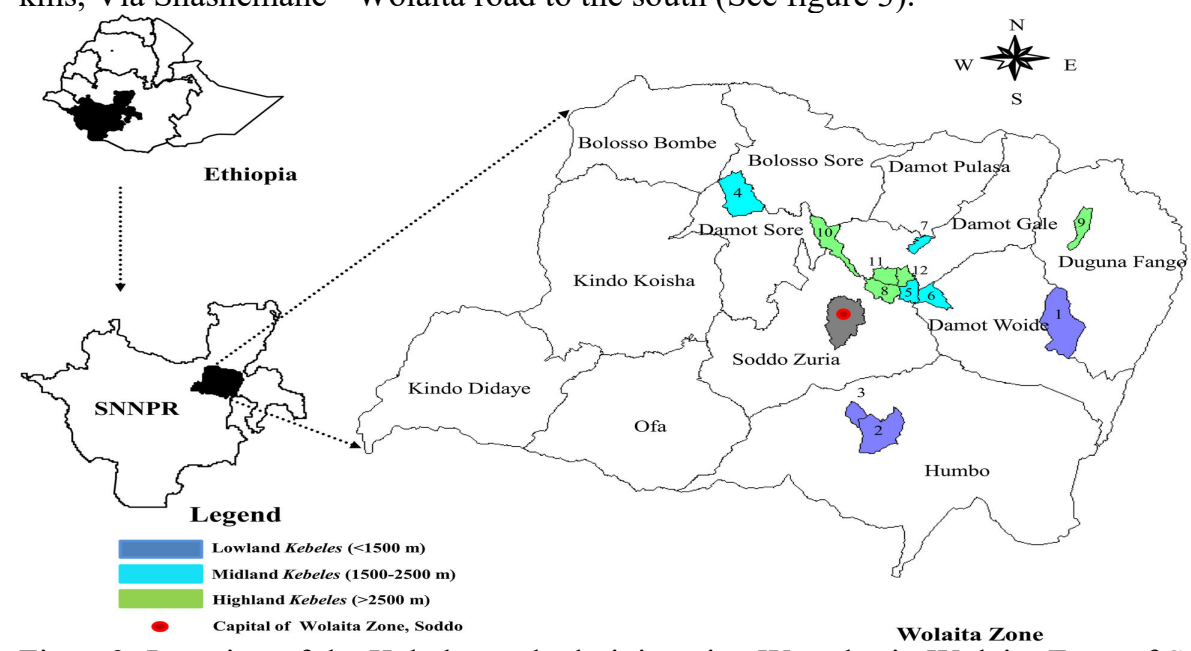

Figure 3: Location of the Kebeles and administrative Woredas in Wolaita Zone of Southern Nations Nationalities and Peoples' Region (SNNPR), Ethiopia, object of the present study. Numbers indicate Kebeles: $1=$ Ankashashara; 2 =Ella-kaballa; 3 = Shochora-agodama; 4 =Afama-amino; 5 = Delbo-atwaro; $6=$ Mayokote; $7=$ Sebaye-korke; 8 = Delbo-wogene; 9 = Dugunaoffa-kalacha; $10=$ Gurumo-koysha; 11 = Shasha-gale; $12=$ Woshi-gale. 
From the selected districts of wolaita zone; Damot Woyide, Humbo, Boloso Sore, Soddo Zuria, Damot Gale, and Dung Fango districts were been selected among 17 rural woredas in Wolaita Zone. This aims at having representation of households with different characteristics in the study.

Based on the 2007 Census conducted by the Central Statistical Agency of Ethiopia, this Zone has a total population of 1,527908, of whom 752668 are men and 775240 women. This zone represents one of densely populated area within the country. According to zonal social- economic profile which indicated in Wolaita zone finance and economic department [38], average population density for zones was about 342 persons per square Kilo meter. While 172,514 or 11.49 percent are urban inhabitants, a further 1,196 or 0.08 percent are pastoralists. A total of 310,454 households were counted in this Zone, which results in an average of 4.84 persons to a household, and 297,981 housing units [38].

The rainfall in Wolaita Zone is typically characterized by seasonality, poor distribution and fluctuation (variability) in amounts from time to time and place-to-place. The mean annual rainfall varies from less than 800 $\mathrm{mm}$ to $1400 \mathrm{~mm}$ with the central part escarpment receiving the highest rain and the lower parts in the eastern and western of the zone receiving the least. The average rainfall for the entire region was 1350 millimeters per year. The short rains or belg is usually occurs in the period of February to May, the main rainy season kiremt from June to September [38].

Temperature in Wolaita Zone varies widely through the diurnal and seasonal variations and with altitudinal zonation. The temperature variation between 24 and $30^{\circ} \mathrm{C}$ during the day and 16 to $20^{\circ} \mathrm{C}$ at night, all year round. Average temperature varies between 16 and $20^{\circ} \mathrm{C}$ in the Zone [38].

Agriculture in this zone is dominated, almost exclusively, as in most parts of the highlands, by small scale and largely subsistence-oriented rain fed crop production. The remainder of the land is under different types of forest and vegetation (grass, shrubs, and trees) used for extensive grazing.

\subsection{Methodology}

\subsubsection{Study Design}

A Completely Randomized Design was been used for analysis of impact and potential of PV applications, a division is made by sectors of rural society: households, social and communal services, off-farm productive uses and agriculture and field survey analysis were done in all selected Villages' of wolaita zone and all experts who are working in Technology distributing centers and energy source related sectors and all government employed women and men who have better experience, knowledge, and belief about impact and potential of PV and utilization. In the area of agriculture and off-farm productive applications an economic criterion (cost comparison and cost-benefit analysis) is deemed of utmost importance to establish the viability of PV applications. In the household sector the quantification or monetization of impacts is far more difficult and the search should be more for beneficiaries' opinions on the impact, supplemented by a cost comparison with other technologies.

\subsubsection{Data Collection}

Both quantitative and qualitative data from primary and secondary sources have been gathered and analyzed. A combination of the following data collection methods were employed for the study.

\subsubsection{Household Sample Survey}

Conventional household survey was adopted for the study as the main method designed to gather quantitative information from sample households using the structured questioner.

\subsubsection{Focus Group Discussion}

Focus group discussions with senior, knowledgeable and well-experienced residents of Wolaita Zone were one of the qualitative data collection methods employed for the study. The discussion was undertaken with two groups that comprised both adult and elderly men and women, with in the range of 10 to 15 individuals for each focus group.

\subsubsection{Key Informant Interview}

Individuals who were considered knowledgeable and rich in experiences about household energy and socioeconomic condition of the residents in Wolaita Zone were identified and interviewed. The key informants interviewed included professionals from different governmental and non-governmental organization, and technology distributers. In addition to the formal interviews, personal experiences and observations of the researcher facilitated the understanding of the overall conditions related to domestic energy use and related significant factors and constraints in the wolaita zone.

\subsubsection{Secondary Data Collection}

By reviewing relevant books and journals, published and unpublished documents the researcher collected secondary data and used the information primarily to set the research context and also to relate the research findings with other empirical studies on the subject of the study. 


\section{Results and Discussion}

\subsection{Results}

One hundred- twenty completed questionnaires were received with a concentration of responses from selected study areas and all experts who are working in Technology distributing centers and energy source related sectors and all government employed women and men who have better experience, knowledge, and belief about impact and potential of PV and utilization (see annex 1). It should be noted that, obviously, the study does not pretend to have a representative sample of responses on which to base conclusions. The survey responses were used as an indicator for impacts and applications, and served to identify other material on the most promising and interesting areas.

Table 3 shows an overview of the survey responses on the uses of PV systems in their projects or business. Note that projects and businesses often involve different applications. More than one application could be filled and therefore the uses total up to more than 100 percent. The table shows clearly that "lighting, TV, radio and other household uses" with the so-called Solar Home Systems (SHS) is the dominant use of PV systems, which is confirmed by literature. Other major applications are for retail shops, cafes and restaurants. Communal use of PV for health centers and community buildings is also a major application. Of the agricultural applications, PV pumping for livestock and irrigation dominate. The prominence of radio and cellular phone communication is confusing, because this category often includes both PV systems used for repeater stations (which do not necessarily directly benefit rural areas), and systems for radio communication by development projects, health centers, rural telecom authorities and private investors (which benefit rural areas more directly).

Table 3 Uses of PV systems (percent of survey respondents)

\begin{tabular}{|l|l|}
\hline Lighting, TV, radio, etc. for household use & $85 \%$ \\
\hline Radio or cellular phone communication & $46 \%$ \\
\hline Health centers (refrigeration, lighting, etc.) & $45 \%$ \\
\hline Lighting and audiovisuals for schools and other community buildings & $40 \%$ \\
\hline Lighting, TV, radio, small appliances for commercial services (retail shop/cafe/restaurant) & $45 \%$ \\
\hline Tourist facilities (lighting, TV, refrigeration of lodges, hotels, etc.) & $11 \%$ \\
\hline Office equipment (computers, etc.) & $12 \%$ \\
\hline Lighting, small power tools for micro-enterprises (repair shop, handicraft) & $15 \%$ \\
\hline Street lighting & $18 \%$ \\
\hline Veterinary service (refrigeration, lighting, etc.) & $10 \%$ \\
\hline Refrigeration (household, retail store, agricultural products, meat, dairy, fish, etc.) & $15 \%$ \\
\hline PV electric fences & $16 \%$ \\
\hline Livestock watering & $5 \%$ \\
\hline PV pumping (irrigation) & $20 \%$ \\
\hline Lighting of poultry /livestock & $11 \%$ \\
\hline PV water purification & $10 \%$ \\
\hline PV pumping (potable water) & $15 \%$ \\
\hline Others, namely: & $1.5 \%$ \\
\hline & $2 \%$ \\
\hline & $1 \%$ \\
\hline
\end{tabular}

Another question referred to the area of impact of the installed PV systems. Table 4 shows an overview of the responses.

Table 4 Impact of PV systems on different rural sectors (percent of survey respondents)

\begin{tabular}{|l|c|}
\hline Households & $85 \%$ \\
\hline Social and community services & $70 \%$ \\
\hline $\begin{array}{l}\text { Off-farm productive uses: rural and cottage industry, commercial services and small business } \\
\text { development }\end{array}$ & $55 \%$ \\
\hline Agricultural productivity & $40 \%$ \\
\hline Other (productive) activities, namely: billboards/advertising & $10 \%$ \\
\hline
\end{tabular}

Again, the majority of respondents noted the impact on households, (mainly SHS), but 70 percent of the respondents also saw impacts on community and social services and more than a third on agricultural or other productive activities. As a combined group, more than half of the respondents saw an impact of PV systems on productive activities (agricultural and/or off-farm productive activities).

\subsection{PV for rural households: Solar Home Systems}

The Solar Home System (SHS) is the dominant application of PV in rural areas of Wolaita Zone and this is reflected by the 85 percent of survey respondents who are involved in such projects. As described earlier, the 
SHS option has been disseminated though a variety of market and social policy approaches which have been analyzed in a vast range of literature. Existing studies cover well the enabling conditions for a successful commercialization or dissemination, but generally do not carry an analysis of the implications on rural development.

A general comment on the SHS performance is that they generally provide a reliable source of electricity. This reliability offers a guarantee of continuous service, especially when the alternative is grid connection with frequent supply interruptions or diesel/gasoline/kerosene options that depend on unreliable access to fuels situations that occur all too frequently in rural areas. This reliability is generally highly appreciated by SHS users but further research is needed to assess the intrinsic (economic) value in terms of the rural development process.

\subsubsection{Impacts of SHS on household economics}

An interesting trend in this context is that the average size of SHSs purchased in the Wolaita zone is growing, as indicated in interviews with representatives of the PV industry. Larger systems should introduce "excess power" beyond lighting and audiovisuals (the main SHS uses). If this trend is confirmed and supported by decreasing PV system prices, there could be a higher potential for impacts on household economics.

\subsubsection{Welfare impacts of SHS}

The following paragraphs summarize information on the (potential) impact of SHS on social welfare, collected through the survey and through the review of literature. A distinction is made between the impacts of the two main services provided, lighting and audiovisuals.

About 85 percent of the survey respondents indicated that the solar systems had an impact on the household quality of life. The quality of lighting output coming from well-designed SHS is much higher than the lighting from kerosene lamps.

The results of the survey confirm that electricity for lighting and TV/radio has several impacts on the quality of life at the household level, especially related to education and homework (82 percent of respondents) and related to recreational activities (84 percent of respondents).

Table 5 Household improvements due to PV electricity (\% of all respondents)

\begin{tabular}{|l|l|}
\hline Better recreation possibilities (TV/radio, reading, etc.) & $84 \%$ \\
\hline Work/education/homework in the evening & $82 \%$ \\
\hline Time liberation, especially for women & $52 \%$ \\
\hline Better health conditions (refrigeration, no smoke, no danger of fire) & $50 \%$ \\
\hline Improvements in housing coinciding with installation & $45 \%$ \\
\hline More pride/self-esteem/positivism & $45 \%$ \\
\hline $\begin{array}{l}\text { Others, } \\
\text { Namely: }\end{array}$ & $15 \%$ \\
\hline
\end{tabular}

The use of SHSs for audiovisuals (radio, TV) can bring the benefits of more access to information and entertainment to the rural villages, but negative impacts are also reported in this context. It is argued that TV programs can create negative impacts in the realm of what could be called "preservation of traditional, cultural values". TV watching is sometimes said to create expectations about (urban) lifestyles, disenchantment with rural life, especially in the young, and thereby to contribute to rural-urban migration in Wolaita Zone.

\subsubsection{Gender-related aspects of SHS impact}

An important aspect of household electrification that has only recently come to the forefront is the different impact on men and women. The feedback from several studies suggests that there is a higher impact on women and children than on men. The former spend more time at home, performing indoor activities, and thus enjoying more the lighting and audiovisuals services from a typical SHS. It is often noted that the quality lighting helps women to do household work more efficiently and children to study after dark. Examples from several countries show that handicrafts, sewing and embroidery are activities that women carry out at home and that access to electricity translates into productivity gains due to factors such as better work schedule management, higher quality lighting, and extended working hours.

A study from Ethiopia case of Wolaita Zone highlights gender specific impacts related to SHS and wind/solar home systems related to the use of time and labour saving home appliances, such as the electric blower for cook stoves: at least 99 percent of interviewed end-users state that electricity has made housework easier and faster for women.

\subsection{PV for social and communal services}

As mentioned in Section 4.1, 70 percent of the respondents indicated an impact on social and community services, especially through improved health facilities, education and community centers as shown in table 6 . 
Table 6 Type of social and community services stimulated with PV (\% of all respondents)

\begin{tabular}{|l|l|}
\hline Education & $56 \%$ \\
\hline (Improved) health facilities & $53 \%$ \\
\hline Public lighting & $23 \%$ \\
\hline Drinking/tap water (including water pumping, purification and desalination) & $22 \%$ \\
\hline Training centers (professional, farmer) & $11 \%$ \\
\hline Community centers/religious centers (churches and mosques) & $57 \%$ \\
\hline Telecommunications & $47 \%$ \\
\hline (Improved) veterinary services & $10 \%$ \\
\hline
\end{tabular}

Table 7 shows that the impacts indicated by the respondents are more or less equally distributed among the different categories.

Table 7 Impact of PV systems for social and community services ( $\%$ of all respondents)

\begin{tabular}{|l|l|}
\hline Better communications and/or information & $60 \%$ \\
\hline More involvement and participation in community development activities & $45 \%$ \\
\hline Higher health standards & $52 \%$ \\
\hline Productive activities/handicrafts (in the evening) & $45 \%$ \\
\hline Courses/classes/training or homework in the evening & $43 \%$ \\
\hline Liberating time of villager for other activities, especially for women & $40 \%$ \\
\hline Better quality courses/training & $35 \%$ \\
\hline Better opening hours shops, restaurants, etc. & $28 \%$ \\
\hline Improvement of local natural environment & $21 \%$ \\
\hline
\end{tabular}

Note that 45 percent of respondents mention that the communal PV systems are also used for productive activities in the evening. No details are available on how many hours, what kind of work and how much more income could be derived from these activities. Most of the impacts of social and community applications of PV are difficult to quantify. In the following paragraphs the main uses of PV systems for social and community services will be discussed.

\subsubsection{PV for health care}

Vaccine refrigeration and ice-pack freezing are the best-known and most common applications of PV in rural health clinics. This equipment is used in immunization programs around the world. Failing reliable refrigeration (along the whole chain: from manufacturing to transport to the point of use), the potency of vaccines is lost. This is, however, generally not visible to the health worker, endangering immunization programs even more. In the most remote health clinics ice-pack freezing is also necessary to carry the vaccines to remote villages in coolers. Electric lighting greatly improves accessibility and quality of (emergency) care at night. Also radio communication can greatly improve rural health care services, by providing full-time communication with medical back-up staff. Recently experiments have been done with remote access to medical databases by internet connection, providing a valuable knowledge source for rural medical personnel. In most instances PV is the only or most cost-effective energy source for these applications. Other medical appliances that can be run on PV systems are nebulizers, centrifuges, sterilization and water treatment equipment.

Finally, remote, unelectrified rural communities have notorious difficulty to recruit and keep trained medical staff. PV systems providing light, music, TV and communication can be important incentives for professional staff (also teachers, extensionists, etc.) to make life in rural areas more amenable.

\subsubsection{PV for schools, community and other public buildings}

The importance of basic education for development, but also of specific training in fields such as agriculture, sanitation and health, goes uncontested, as it allows people to strengthen their skills and abilities; to become more productive; and to feel empowered by knowledge on the world around them. Many studies have shown that, also on the (macro) economic level, education is one of the best investments, outstripping many investments in physical capital. Energy can make only a small contribution to this, but as more effective (and efficient) teaching methods are developed, simple (electrically powered) audio-visual aids can have a high impact on the access to, and quality of, education. These aids can vary from the advanced to audio-visual aids (such as video) supporting classroom and training programs, to cheap and effective distant learning methods for basic adult education programs transmitted by radio and cassette. In all cases adequate lighting can help extend the "learning" day in our study area.

As in the health care sector, the observation is often made that basic lighting and audiovisuals can also help professionals working in remote areas to increase their standard of living and motivate them to stay. Also it allows them to prepare classes at night and stay informed, through radio and TV, which should have their effect on the quality of classes.

In remote rural villages, schools and other community centers (churches, mosques) are often a focal point for the community, with great potential for the integration of community development and educational goals in 
Wolaita Zone. Basic lighting in the evening can facilitate after-dark activities like community reunions, adult education, religious activities and festivities. Of the cases in the questionnaire involving PV systems for community centers, schools and other public buildings, around 45 percent mentioned productive activities as one of the evening activities in these centers, mainly relating to sewing and handicrafts making. These buildings are often the only buildings in a village that have good quality lighting.

\subsubsection{Other social and communal uses of PV systems}

As described in literature telecommunication makes up a large share of the market for PV panels. The larger part of this share, however, goes to repeater stations and other infrastructure for general support of telecommunications networks, of which rural areas gain little direct benefits. Urban based mobile telephone networks, for instance, often have repeater stations that are situated on mountain tops in rural areas, but this does not necessarily indicate rural inhabitants benefit from this in a major way. Without the necessary support infrastructure, these installations are as useful to rural inhabitants as a high voltage transmission line that passes through an unelectrified village. This support infrastructure is limited by a balance between the amount of investment and expected connections, just as in ground-based telecommunication systems. Continuing advances in radio and especially mobile telephone communication have considerably lowered investments in support infrastructure, especially for remote, hilly and otherwise inaccessible areas. PV is by far the preferred and most reliable power source for most remote telecommunication infrastructure. Single radio-connections and mobile phones can be run on small solar panels (10 to $50 \mathrm{Wp})$. The reliability and easy maintenance of PV systems also makes these services more reliable in Wolaita Zone.

Many of these mobile networks run on a for-profit basis, but in other cases national governments invest in telecommunication to connect remote rural areas to the rest of the country. Many telecommunication connections are based in development projects, hospitals and other semi- public institutions, where they make invaluable contributions to improved services (varying from logistical arrangements to medical consultations and emergencies). If telecommunication is open to the public, rural inhabitants not only use them for social purposes, but also for productive purposes, such as the example of farmers in Wolaita Zone who can check Cash crops prices in the city, before selling their crops to intermediaries, thereby greatly improving their bargaining power. These telecommunication services often prove so popular, that in many rural areas of Wolaita Zone.

Another type of PV system that is finding increased communal application is the PV battery charging station in Wolaita Zone. Many rural inhabitants already use old car batteries for TV and a single light, charging them in electrified villages at considerable distance and price. Solar battery charging stations provide an intermediate level between these "conventional" battery charging practices and a privately owned solar system. Most experiences with solar battery charging stations have been with government-subsidized programs, often managed by community groups. However, decreasing prices and continuing project experience, have opened solar battery charging as an option for investment by local entrepreneurs.

\subsection{PV for off-farm productive uses}

The analysis of PV electrification programs, through the survey and through analysis of project documents and interviews with experts, shows there is a growing number of an off-farm productive activity among rural people whose productivity depends on or may be enhanced by the input of electricity in Wolaita Zone.

Among these activities there are a number that can be efficiently powered by small solar systems, thus creating an opportunity for productive use of solar electricity. As indicated in Section 4.1, the survey found that about 55 percent of the respondents are of the opinion that PV systems have produced an impact on cottage industry and commercial activities, and small business development. The relevance of small PV systems for productive uses is, however, limited to the provision of power for off-farm activities that require little power input. PV systems are not an option for energy intensive activities such as in rice mills and other agricultural processing. One of the premises of this study is, however, that "Small loads from PV systems can be carriers of rural socio-economic development."

Table 8 summarizes the breakdown of income generating activities identified from the survey findings. The impact on small retail shops, recreational services (bar, cinema) and handicraft and sewing workshops is most often reported (32, 25 and 27 percent respectively), while a more limited experience is reported with such pioneering activities as battery charging stations and telephone centers ( 35 and 15 percent respectively).

Table 8 Businesses created or improved with PV (\% of all respondents)

\begin{tabular}{|l|l|}
\hline Battery charging & $35 \%$ \\
\hline Retail shops/restaurant/bar & $32 \%$ \\
\hline Rural cinema (TV/video-business) & $25 \%$ \\
\hline Handicrafts/sewing workshops & $27 \%$ \\
\hline Repair/technical shops & $23.5 \%$ \\
\hline Telecommunication shops (mobile phone shops) & $15 \%$ \\
\hline Tourism (hotel, lodge) & $11 \%$ \\
\hline
\end{tabular}


Table 9 shows an overview of survey responses qualifying the major types of development impacts derived from the solar electricity input for productive activities. The results indicate that respondents most often identify the benefits of lighting, which allows longer working and opening hours (51 percent). A lower but significant percent of respondents indicated the impacts consisted of higher productivity (30 percent), increased quality of service due to higher attractiveness for customers ( 29 percent), and more employment ( 25 percent) followed by the creation of new home/cottage industry productive activities (18.5 percent).

Table 9 Impact of PV on business activities (\% of all respondents)

\begin{tabular}{|l|l|}
\hline Longer working hours/longer opening times & $51 \%$ \\
\hline Better quality service (e.g. more attractive business through provision of light, music, cold drinks, etc.) & $29 \%$ \\
\hline Higher productivity & $25 \%$ \\
\hline More employment & $25 \%$ \\
\hline $\begin{array}{l}\text { New business opportunities through use of new equipment (power tools, telephone, etc.) or new, more } \\
\text { marketable products (e.g. handicrafts) }\end{array}$ & $20 \%$ \\
\hline Better quality products (higher price) & $13 \%$ \\
\hline Creation of home/cottage industries & $18.5 \%$ \\
\hline More sales & $15.5 \%$ \\
\hline
\end{tabular}

\subsubsection{PV for cottage industry and commercial businesses}

One of the most commonly reported examples of productive use in rural businesses is related to the prolonged working hours due to lighting. Lighting is reported to improve also the quality of the productive activity and to attract more customers, according to the nature of the business. In the survey, 32 percent of respondents indicate that retail shops, cafes and restaurants were created, stimulated or improved by the provision of solar electricity. Apart from lighting in such businesses PV provides power for music, TV and simple devices such as blenders. The survey responses do not go into enough detail to derive data on income generation from these activities.

The information gathered from the survey also shows the potential for using solar systems in small technical workshops (23.5 percent of the respondents). Often electronic repair shops are reported to receive benefits from some electricity supply. They can easily power monitoring devices and small tools such as the soldering irons, which can improve the quality of repair and the productivity of the workshop with very limited power demand. As indicated in the inventory of applications, repair workshops have made use of solar electricity for powering small drills, employed, for instance, in bicycle repair shops. Such low power DC tools can also improve the quality and productivity of handicrafts, such as in woodwork and bamboo craft workshops.

The powering of tools for off-farm activities with small PV systems encounters obvious limits on the power supply side: the larger the electricity demand, the higher is the chance for diesel or gasoline-run gensets. This is similar to the case of refrigeration: small energy efficient units (up to 200-300 lt.) can be powered with a small PV supply, but when the demand is for large refrigeration units the PV option often becomes too costly.

\subsubsection{PV for service businesses}

One of the simplest examples of rural income generation with PV is the sale of electricity: a sort of rural electric micro-utility. Traditionally the more affluent families in the villages who own a small diesel generator sell electricity to their neighbors. A recorded example of such a "micro-utility business" with a PV system is now not being monitored in Wolaita zone. The diffusion of village-size solar battery charging (BCS) stations is instance of micro-utility which generates rural income and employment of our study area.

Another promising PV-powered service business is the rural telephone service. Today, solar powered satellite telephone booths developed by Ethiopia telecommunication provide the service to remote areas in 17 different Woredas in Wolaita Zone.

Recreational service businesses are expanding in many rural areas and they are usually dependent on a small electricity supply for powering lights, colour TV, DSTV, videos and music systems. These solar system applications often build on (and replicate) local past experience with the sale of TV service by an affluent family owning a small kerosene or diesel generator. In Wolaita zone, for instance, over 17 youth center systems that are equipped with lighting, TV/VCR, music, DSTV, and battery charging service were installed. When the local operator is able to acquire good videocassettes, these centers experience success in selling the tickets for films together with snacks and drinks, thus contributing to the cash flow of the battery charging service.

\subsection{PV for agriculture}

As indicated in Section 4.1, 40 percent of respondents indicated an impact on agriculture, mainly through activities in irrigation, livestock watering and electric fencing as shown in table 10. 
Table 10 Agricultural activities stimulated with PV (\% of all respondents)

\begin{tabular}{|l|l|}
\hline Irrigation & $15 \%$ \\
\hline Water pumping for cattle drinking & $14 \%$ \\
\hline Lighting (poultry, livestock) & $6 \%$ \\
\hline Water pumping for fish farming & $2 \%$ \\
\hline Refrigeration of crops/meat/fish/dairy/other & $2 \%$ \\
\hline Light for fishing & $2 \%$ \\
\hline Electric fencing for grazing management & $3 \%$ \\
\hline Light for fish processing & $2 \%$ \\
\hline Pest control & $1 \%$ \\
\hline
\end{tabular}

Table 11 shows that the main impacts indicated by the respondents were increased productivity (including higher yields, lower losses and faster production) and improved natural resource management.

Table 11 Impact of PV systems on agriculture (\% of all respondents)

\begin{tabular}{|l|l|}
\hline Higher productivity (higher yield) & $36 \%$ \\
\hline New, more marketable product & $27 \%$ \\
\hline Multiple crops per year & $25 \%$ \\
\hline Better quality product (higher prices/more sales) & $24 \%$ \\
\hline More animals can be raised & $22 \%$ \\
\hline Lower losses (death rate) or faster production & $21 \%$ \\
\hline Better natural resource management & $15 \%$ \\
\hline More land to be cropped & $13 \%$ \\
\hline Access to more profitable markets (e.g. through conservation of product for transport) & $2 \%$ \\
\hline Others, $\quad$ Safer fishing & $2 \%$ \\
\cline { 2 - 3 } & Cost savings through production instead of purchase of forage (micro-irrigation) \\
\hline
\end{tabular}

Although the survey responses do not go into sufficient detail to be able to do in-depth cost benefit analyses and they are too few to serve as a representative sample, with the help of literature it is possible to make general comparisons for the economic competitiveness of different applications. The main agricultural uses of PV for agriculture are discussed in the literature and an attempt is made to outline the conditions under which PV is already or potentially cost-competitive.

Many different figures exist in literature on the comparison of PV and other pumping technologies. All agree on the fact that investment costs in PV pumping equipment are much higher than the alternatives (diesel, electric), but on a life-cycle basis, PV pumping can be economically more competitive. The relative advantage of PV pumping is in the low-water use and low pumping head (low power) range. Other advantageous aspects are low-maintenance and high reliability (if projects are well designed and organized). PV pumping is therefore very suitable for drinking water supply in remote unelectrified villages and often the least-cost solution on the basis of life-cycle costing. Also, for livestock watering, PV pumps are often the least-cost solution and widely used.

As livestock operations improve, watering places in addition to natural water sources become necessary. Effective watering systems are also needed to protect watercourses and to improve the availability of good quality water. PV pumping for cattle-watering is one of the alternatives that are gaining prominence in off-grid areas. Of the survey responses involved in cattle-watering, the main positive impacts mentioned are: increased cattle production on existing lands (both of milk and meat), and improved natural resource management.

PV powered pumps are one of the alternatives for improved livestock watering systems. PV systems have the advantages of mobility, little maintenance and no need for supervision or fuel supply. A specific characteristic of PV pumping systems is that they generally do not need a battery for back-up, but use a water tank, which reduces maintenance and increases system reliability. However, investment costs in PV systems are high, which makes them mainly attractive for large herds. A problem often mentioned is the vulnerability to stealing and/or damaging of the systems in remote, unattended locations. Though investment costs are high, PV pumps for livestock watering are not widely commercially available in Wolaita Zone.

\subsection{Discussion}

In this part the most important PV applications were discussed - both in terms of present use and in terms of (potential) impact - with a special focus on productive applications in rural areas of Wolaita Zone.

Solar Home Systems (SHS) are still the dominant PV application in rural areas of Wolaita Zone and their main use is for lighting and radio/TV in households. The evidence of the impact of SHSs on household economics is mixed: some studies report that there is little evidence of such direct impacts; others make reference to time savings and extension of the day due to SHSs. This "surplus time" is sometimes used for productive activities such as sewing, basket weaving and handicraft making. In other cases this "surplus time" is 
used for facilitating household chores, homework, education and recreational activities. The acquisition of SHSs generally results in savings on other energy expenditures (especially kerosene), but this is often more than compensated by the additional expenditures on SHSs (for example, payments on loans, maintenance). Rural people's willingness to pay several times their "normal energy budget", is a clear sign of the value they attach to the improved services of SHSs. Often mentioned aspects include: decrease in accidental fire, improved quality lighting, improved education, improved access to information and improved health/hygiene.

Women and children are often found to be the main users of SHS in Wolaita Zone, because they spend more time in and around the house and they are also more confronted with system failures. Still most marketing, financing and training efforts are directed towards men. Slowly this appreciation is trickling down to the practitioners of PV and having its impact on training programs and projects. A trend noticed is the widening of delivery mechanisms for PV electricity, including leasing, which improves the access of lower income groups to these services. Another trend that is detected is the growing system size of PV installations in Wolaita Zone. Examples show that this can translate into more power becoming available for other uses than lighting and radio/TV.

Many PV projects have been and are being implemented for social and communal services, such as refrigeration, communication and lighting for health centers; provision of potable water and basic lighting for schools and communal buildings. In many cases PV has shown to be the least-cost solution to improving such services in remote areas of wolaita Zone. With relatively small investments, PV systems can have a significant impact on the lives of all rural inhabitants through these improved services, providing that access to these services by marginalized groups is accounted for. One of the important lessons learnt in such projects, is the importance of adequate community organization and financing of operation and maintenance. Successful examples exist where some kind of income-generating activity is integrated into the communal service to contribute to a fund for operation and maintenance (for example, by running a small village cinema or battery charging station).

Small PV systems also help develop off-farm productive activities (both cottage industry and commercial services) in Wolaita Zone, by powering small tools and appliances (drills, soldering irons, and blenders), lighting and radio/TV. These activities include bars, restaurants, and rural cinemas, technical and artisanal workshops. The amount and diversity of these PV applications for off-farm productive activities is enormous (see table 4 for an overview), but too little information was found to quantify this potential. Often these activities take place at home and are therefore difficult to distinguish from other home activities as described under the SHS-section. Other off-farm productive activities that are increasingly powered by PV systems are telephone services and the sale of electricity itself: more and more local entrepreneurs and community groups run solar battery charging stations or sell electricity in other ways. Finally, the servicing and installation of PV systems themselves is often based on networks of solar micro-enterprises that are often situated close to their source of business in rural areas, creating more local employment.

There are also a growing number of uses of PV for agricultural productive applications. Water pumping (for livestock watering, irrigation as well as potable water) has gained prominence. PV systems are often already the most economical solution for watering livestock in remote, unelectrified areas but are not widely commercially available in study area. Though still needing affordability (cost of the technology relative to farmer income levels), awareness (knowledge about the technology), accessibility (options for obtaining the technology), and lack of customization (capacity to match farmer needs with technological solutions). The combination of PV pumps with drip and other "efficient" irrigation techniques promises an economic solution for irrigation of horticultural and other high value crops with less water and fertilizer, even for lands that were formerly judged as unsuitable for irrigation.

\section{Conclusions and Recommendations}

\subsection{Recommendations to promote PV for SARD}

The following are recommendations arising from the study with the aim to use the opportunities that PV systems offer in contributing to Sustainable Agriculture and Rural Development. These recommendations are the result of an assessment of the experiences collected in this study, enriched with other discussions and inputs. They are intended to provide a set of activities for different stakeholders involved in the process of PV rural electrification and rural development.

- Demonstration and promotion are required for PV applications such as drip-irrigation, cattle watering, PV electric fences and aquaculture applications as an integral part of agricultural development programs;

- Demonstration and promotion of small PV systems for small cottage industry activities are needed to increase the awareness and knowledge of PV contribution to micro-enterprise development. A possible and innovative approach could be based on PV powered micro-enterprise development zones or PV business incubator approaches, through the installation of multi-purpose or multiservice PV units, that 
can deliver power for income generating activities;

- Agriculture and other rural extension services should become agents to identify potential PV applications; information and training in this field is required;

- Development banks should include PV systems as eligible for loans; the PV systems themselves can function as collateral, especially when they are investments for productive uses; multilateral investment banks and other financing organizations may develop loan guarantee funds to support these solar loan portfolios;

- As for many other products, equal access to credit by women is required, which would increase their chances to use PV for household and income generating opportunities;

- Private sector investments can and should be attracted for financing of PV electrification programs; international donor funds, soft terms loans and other seed capital can be used as leverage for such private sector investments;

- Training packages are required for preparing PV installation, operation, maintenance and repair services, but also in the use of PV for various agricultural applications, e.g. improved irrigation techniques;

- Intersectoral efforts are required to bring closer the plans, programs and policies identified above; this involves the agriculture, energy, health, education and environmental sectors in particular;

- Synergies as identified when PV applications are promoted simultaneously and in an integrated approach in various sectors should be built into collaborative implementation and marketing strategies;

- Developing plans of action for the integration of rural energy delivery programs with micro-enterprise development programs; mutual benefits could be gained: PV electricity rural markets can become a source and stimulus for both Energy Service Companies and for small "electrified" entrepreneurial activities;

- Since PV systems normally require more "involvement of the end-user" than conventional grid electricity, the involvement of farmers' and other end-users' organizations in all phases of the PV program design and implementation is critical; failure to achieve an ownership feeling will most probably lead to failure of the program.

- National governmental policies need to be established to promote the important role that renewable energies in general, and solar photovoltaic systems, in particular, can play in achieving sustainable agriculture and rural development;

- These policies should also create the appropriate environment and the necessary regulatory and normative context for the role of the private sector and non-governmental institutions;

- Research is further needed to assess the replicability of promising PV applications and the conditions under which they are successful; and to develop approaches for assessing their cost/benefit ratio;

- Further research efforts are required for the optimization of PV systems for agricultural use in order to develop complete services or product packages, e.g. optimized irrigation systems (panels, electronics, pumps and drip-irrigators) for economic irrigation and fertilization; such packages should be adapted to local agronomic, soil and water and ecosystems and should be accompanied by adequate training packages;

- Other areas of continued research and development are low energy consuming appliances (such as affordable low energy consumption refrigerators) and PV/diesel and PV/wind hybrid energy systems;

\subsection{Conclusions}

It can thus be concluded that PV applications, and especially those for productive activities, have considerable potential to both serve environmental concerns (e.g. climate change) and contribute to the achievement of sustainable agriculture and rural development. All stakeholders involved in the dissemination and use of these applications need to play their respective roles in order to achieve that potential. It is hoped, in particular, that international cooperation agencies and government commit themselves to assisting Wolaita Zone in making use of this potential, particularly in the process of promoting sustainable agriculture and rural development.

Recalling the importance of cross-sectoral cooperation to fully maximize this potential, the study will hopefully contribute to underscoring government and international cooperation agencies role in promoting the integration of PV systems in agriculture. It is also recommended that government actively looks for cooperation and alliances with other interested parties.

A fast and successful dissemination strategy has to include local availability of PV systems, training of solar experts, local solar businesses, exchange of information about end users' needs and manufacturers, which might be achieved by local solar production, adapted appliances, financing schemes and model projects. Beneficial economics of PV in Wolaita Zone could generate additional purchasing power and PV service jobs in rural villages. Access to electricity has the potential for sustainable rural development and a new "enlightenment" in rural areas. 


\section{References}

[1] AAU, 2001. Renewable Energy Resources Technology Faculty of Technology Electrical Engineering Department, Study of Feasible Options for Rural Electrification in Ethiopia, Final Report Vol. II, Addis Ababa, Ethiopia.

[2] Getachew Bekele, 2009. The Study into the Potential and Feasibility of Standalone Solar-Wind Hybrid Electric Energy Supply System for Application in Ethiopia, KTH Royal Institute of Technology Doctoral Thesis, December 2009.

[3] Getnet Tadesse, 2011. Feasibility Study of Small Hydro/PV/Wind Hybrid System for off-Grid Rural Electrification in Ethiopia. Addis Ababa Institute of Technology Department of Electrical and Computer Engineering

[4] Oliver, P., 2002. Micro-hydro Power status and prospect UNCC, Addis Ababa, 21-22 March 2002.

[5] Yacob Mulugeta., 1999. Energy in Rural Ethiopia: Consumption Patterns, Associated Problems, and Prospects for a Sustainable Energy Strategy, Energy Sources, Part A: Recovery, Utilization, and Environmental Effects.

[6] Yacob Mulugeta and F. Drake, 1996-a. Assessment of Solar and Wind Energy Resources in Ethiopia: Part I. Solar Energy, Vol. 57, No.3, pp. 205-217 School of Geography, University of Leeds, Leeds LS29JT, U.K.

[7] United Nations, World Population Prospects: The 2006 Revision Highlights, UN Department of Economic and Social Affairs, Population Division, Working Paper No. ESA/P/WP.202, New York, 2007,

[8] United Nations, Human Development Report 2007/ 2008, UN Development Program, New York, 2007,

[9] Solar Energy Foundation, Addis Ababa, Ethiopia, www.solar-energy-foundation.org

[10] T. Huld, M. Š́ri, E. Dunlop, M. Albuisson, L. Wald, 2005. Integration of HelioClim-1 database into PVGIS to estimate solar electricity potential in Africa, Proceedings 20th European Photovoltaic Solar Energy Conference, Barcelona, 2005, June ,6-10

[11] Ethiopian Electric Power Company (EEPCo), Electricity Power Industry Master Plan Program, Addis Ababa, 2007, www.eepco.gov.et/psdp_progsummary.html

[12] Deutsche Gesellschaft für Technische Zusammenarbeit (GTZ), Energy-policy Framework Conditions for Electricity Markets and Renewable Energies, Division Environment and Infrastructure, Eschborn, 2007

[13] Kreditanstalt für Wiederaufbau (KfW), PV-Hydro Initiative: Stages $1 \& 2$ - Assessment of the Potential for the Commercialization of Conjunctive Photovoltaic - Hydro Power Generation, KfW and United Nations Environmental Program (UNEP) prepared by Lahmeyer International and Solar- Institut Jülich, 2001

[14] Kreditanstalt für Wiederaufbau (KfW), EMPower Phase I: Utility Case Studies - Final Report, KfW and United Nations Environmental Program (UNEP), 2007

[15] G. Knies (ed.), Clean Power from Deserts - The Desertec Concept for Energy, Water and Climate Security, DESERTEC Foundation, Protext Verlag, Bonn, 2009

[16] W. Short, D.J. Packey, T. Holt, 1995. A Manual for the Economic Evaluation of Energy Efficiency and Renewable Energy Technologies, National Renewable Energy Laboratory (NREL), NREL/TP- 462-5173, Golden

[17] Ch. Breyer, A. Gerlach, M. Hlusiak, C. Peters, P. Adelmann, J. Winiecki, H. Schützeichel, S. Tsegaye, W. Gashie,2018. Electrifying the Poor: Highly Economic Off-Grid PV Systems in Ethiopia - A Basis for Sustainable Rural Development

[18] Ch. Breyer, A. Gerlach, J. Mueller, H. Behacker, A. Milner, Grid-Parity Analysis for EU and US Regions and Market Segments - Dynamics of Grid- Parity and Dependence on Solar Irradiance, Local Electricity Prices and PV Progress Ratio, this conference

[19] A. Gerlach, Wirtschaftlichkeit von Photovoltaik in nicht subventionierten Märkten, Diploma thesis, Clausthal University of Technology, 2009

[20]N. Peterschmidt, J. Schmidt-Reindahl, H.-P. Beck, J. Baur, Taking the step from Solar-Home-Systems to Micro-Grids: The business model of micro power economy for rural electrification in Senegal, Proc. 4th European PV-Hybrid and Mini-Grid Conference, Athens, 2008, May, 29 - 30

[21] S.M. Schoenung, W.V. Hassenzahl, 2003. Long- vs short-term energy storage: Technologies analysis - A life-cycle cost study, Sandia National Laboratories, SAND2003-2783, Albuquerque

[22] Deutsche Gesellschaft für Technische Zusammenarbeit (GTZ), GTZ International Fuel Prices $6^{\text {th }}$ Edition Data Preview, Division Transport and Mobility, Eschborn, 2009, www.gtz.de/de/dokumente/eninternational-fuelprices- data-preview-2009.pdf

[23] P. Jourde, Battery energy pay-back time, Proceedings $16^{\text {th }}$ European Photovoltaic Solar Energy Conference, Glasgow, 2000, May, $1-5$

[24] U. Bardi, Peak oil: The four stages of a new idea, Energy 34 (2009) 323

[25] on the occasion of the "Solar Energy Training for Energy Sector Decision Makers and Experts", organized by Solar Energy Foundation, Addis Ababa, Ethiopia, 2008, September 15 - 25

[26] T. De Villers, Terminal Evaluation of the project 'Building Sustainable Commercial Dissemination 
Networks for Household PV Systems in Eastern Africa', Project No: GF/4040-04-22, United Nations Environment Program (UNEP), Nairobi, 2007, www.unep.org/eou/Pdfs/Household_PV.pdf

[27] M. Shanko, H. Lakew, A. Kyezira, 2006. Rural solar PV market potential: A case for Jima region in Ethiopia, Megen Power Ltd., Addis Ababa

[28] H. Gabler, Photovoltaik zur netzfernen Energieversorgung, Zentrum für Sonnenenergieund WasserstoffForschung (ZSW), 23.Symposium Photovoltaische Energieversorgung, Bad Staffelstein, 2008, March, 5 - 7

[29] P. Adelmann, Wireless Power, Maputo Workshop for SSA Electrification Experts, Maputo, 2009, June, 9 12

[30] A.S.A.C. Diniz, J.G.F. Rosa, J.A. Burgoa, C.A. Alvarenga, Rural school photovoltaic electrification in the state of Minas Gerais - Brazil, Proceedings 2nd World Conference on Photovoltaic Solar Energy Conversion, Vienna, 1998, July, 6 - 10

[31]. FAO. 2012. Mapping and assessing the potential for investments in agricultural water management: The Federal Democratic Republic of Ethiopia, Country Investment Brief, FAO Water; Ag Water Solutions Project. Rome, Italy: Food and Agriculture Organization of the United Nations (FAO).

[32]. Mendes, D.M.; Paglietti, L. 2015. Ethiopia: Irrigation market brief. Country highlights. Rome, Italy: Food and Agriculture Organization of the United Nations (FAO); Washington, DC: International Finance Corporation (IFC).

[33]. World Bank. 2012. Ethiopia - Electricity Network Reinforcement and Expansion Project (ENREP).Project Appraisal Document. Washington, DC: World Bank. Pp.9

[34].UNFCCC, (United Nations Framework Convention on Climate Change), 2016. Program design document form for small-scale CDM programs of activities (version 04.0). Ethiopia off Grid Renewable Energy Program, Version 06

[35]. MoWIE (Ministry of Water, Irrigation and Electricity) 2016. Rural electrification, Addis Ababa, Ethiopia: Federal Democratic Republic of Ethiopia.

[36]. Alemayehu, T. 2016. Rapid assessment report on status of solar energy development and solar pump use in Ethiopia, Internal Report, Colombo, Sri Lanka: International Water Management Institute (IWMI).

[37]. Chesbrough, H.W. 2010. Business model innovation: Opportunities and barriers. Long Range Planning 43(2-3): 354- 363.

[38] CSA, (2007). Population and Housing Census of Ethiopia

\begin{tabular}{|c|c|c|c|}
\hline \multirow[b]{2}{*}{ Company } & \multirow[b]{2}{*}{ Main activity } & \multicolumn{2}{|c|}{ Contact information } \\
\hline & & Telephone & E-mail \\
\hline $\begin{array}{l}\text { Fosera } \quad \text { Manufacturing } \\
\text { PLC }\end{array}$ & Manufacturer & +251910372072 & $\begin{array}{l}\text { http://www.fosera.com| } \\
\text { thomas.koepke@fosera.com }\end{array}$ \\
\hline $\begin{array}{l}\text { Metals \& Engineering } \\
\text { Corporation }\end{array}$ & Manufacturer & & \\
\hline Carlo & Manufacturer & & \\
\hline $\begin{array}{l}\text { Selam Technical \& } \\
\text { Vocational Center }\end{array}$ & $\begin{array}{l}\text { Manufacturer } \quad \& \\
\text { testing }\end{array}$ & +25111462956 & selamtvc@telecom.net.et \\
\hline Tehadiso Ethiopia & $\begin{array}{l}\text { Manufacturer\& } \\
\text { retailer }\end{array}$ & +2519243653 & \\
\hline RET Energy Engineering & $\begin{array}{l}\text { Manufacturer } \quad \& \\
\text { retailer }\end{array}$ & +251912501796 & \\
\hline $\begin{array}{lll}\text { EMU General Importer } \\
\text { PLC }\end{array}$ & Importer & +251115523131 & emu@ethionet.et, \\
\hline $\begin{array}{l}\text { Solar and Information } \\
\text { Technology plc. }\end{array}$ & Importer & +25114163449 & \\
\hline $\begin{array}{l}\text { SOLAR23 Development } \\
\text { PLC }\end{array}$ & Importer & +251922172069 & \\
\hline Solar Woman & Importer \& supplier & +251113200021 & www:solarwomanethiopia.com \\
\hline $\begin{array}{l}\text { Equatorial Business Group } \\
\text { PLC }\end{array}$ & Wholesaler\& retailer & +251114424955 & ebg@ethionet.et \\
\hline Eternum Energy Ventures & Importer\& supplier & +251921563060 & http://www.dungoenergy.com \\
\hline $\begin{array}{l}\text { Davis and Shirtliff } \\
\text { Ethiopia PLC }\end{array}$ & $\begin{array}{l}\text { Trading Supplier\& } \\
\text { distributor }\end{array}$ & +251115159341 & ethiopia@dayliff.com \\
\hline $\begin{array}{l}\text { TENSAE International } \\
\text { Business Enterprise Plc. }\end{array}$ & Supplier \&installer & +251118501458 & Biruk.tensae@gmail.com \\
\hline
\end{tabular}




\begin{tabular}{|l|l|l|l|}
\hline & & \multicolumn{2}{|c|}{ Contact information } \\
\cline { 3 - 4 } Company & Main activity & Telephone & E-mail \\
\hline Lydetco Plc. & Supplier \& installer & +251114667153 & lydetco@ethionet.et \\
\hline $\begin{array}{l}\text { Bruh Tesfa Irrigation and } \\
\text { Water Technology Plc }\end{array}$ & Supplier \& distributor & +251115157622 & Bruht-aa@ethionet.et \\
\hline Green Power Africa Plc. & Supplier \& distributor & +251116632357 & www.greenpowerafrica.com \\
\hline Admas Solar & Supplier \& distributor & +251911306530 & yetema45@yahoo.com \\
\hline Auto Truck & Supplier \&distributor & +251911206362 & autotruck-plc@hotmail.com \\
\hline Direct Solar Energy & Supplier \&distributor & +251115529178 & \\
\hline Ever Bright & Supplier \& distributor & +251114420028 & \\
\hline Mara Trade & Supplier \& distributor & +251913256064 & mymara00@gmail.com \\
\hline RET Energy Engineering & Supplier \& distributor & +251912501796 & retenergyengineering@gmail.com \\
\hline $\begin{array}{l}\text { SOL Solar } 23 \\
\text { Development }\end{array}$ & Supplier \&distributor & +251911646120 & \\
\hline Solar Light Energy Africa & Supplier \&distributor & +251115516025 & \\
\hline $\begin{array}{l}\text { Solar Woman (Tigist } \\
\text { Tadesse) }\end{array}$ & Supplier \&distributor & +25113200021 & solartech_eth@yahoo.com \\
\hline Sun transfer Tech & Supplier \& distributor & +251911689292 & yonas@suntransfer.com \\
\hline Vonall Com & Supplier \&distributor & +251115511659 & info@vonall.com \\
\hline Electric World P.L.C. & Supplier \& distributor & +251111565838 & \\
\hline Biselex Ethiopia P.L.C. & Supplier \&distributor & +251116628600 & biselexet@biselexgroup.com \\
\hline Wonderwheel Business & Supplier \&distributor & +251911207227 & seife@orchidbg.com \\
\hline $\begin{array}{l}\text { MEGEN Power (MGP) } \\
\text { Ltd. }\end{array}$ & $\begin{array}{l}\text { Consulting company } \\
\text { \& trainer }\end{array}$ & +251911203097 & \\
\hline Sat Solar Engineering & Supplier \&distributor & +251115545861 & \\
\hline Sky Solar & Supplier \&distributor & +251111239927 & \\
\hline Vizzer Viorino & Supplier\& distributor & +251116293412 & \\
\hline Direct Solar Energy & Supplier \&distributor & +251115529178 & \\
\hline
\end{tabular}

\section{Annex2: Survey questionnaire}

Study on the Impact of Solar Photovoltaic Systems on Rural Development in Wolaita Zone

Filling in the questionnaire

This questionnaire is directed at key-persons - like you - involved in the organization, distribution, finance, installation and/or maintenance of PV-systems in rural areas and asks your assessment of the impact of PVsystems you are involved in or have immediate knowledge of.

Note: If you work in more than one PV-project or market, please fill in a separate questionnaire per project or choose one (preferably the one with the largest income-generating component).

The questionnaire has been structured in 3 parts:

Part 1 (chapter 1) contains general questions on the PV-project and systems and on the general area of impact and main beneficiaries. It also serves as a selection for part 2 of the questionnaire.

Part 2 (chapters 2 - 5) contains the main questions on the impact of the PV-systems on different aspects of rural development. In general, only one or two of these chapters will have to be filled per questionnaire, depending on the main area of impact.

Part 3 (chapter 6 and 7) lists questions on the organization and financing of the PV-systems. Chapter 7 contains some open questions on your ideas/opinions of how to improve the impact of PV-systems on rural development in Wolaita Zone.

Most of the questions are of a 'checklist'-nature, in which case one or more boxes should be checked. For the few open questions space has been left open in text boxes to write down your answer.

\begin{tabular}{|l|l|}
\hline \multicolumn{2}{|c|}{1.1 Personal Data } \\
\hline Name of respondent & \\
\hline Organization & \\
\hline Address mail address & \\
\hline Mobile & \\
\hline email & \\
\hline
\end{tabular}


1.2. If your organization is involved in different $P V$-projects or sells different types of $P V$-systems, could you indicate what the $\mathbf{P V}$-systems are used for and possibly give a percentual breakdown?

Productive uses agriculture, rural/cottage industry, small business

Community/social services village water pumping, health centers, schools, etc.

Solar home systems

Other, namely

1.3. Geographical location of the PV-project or market

Village/Town/City if applicable

Region/department/province

Country

1.4. Type of PV-systems used/sold please tick box, more than one if appropriate

Centralized village mini-grid

Solar Home System (= small system for lighting, TV/radio, etc. for home, school, bar, etc.)

Other stand-alone system (pumping, refrigeration, desalination, etc.)

Hybrid system PV and $\square$ diesel or $\square$ wind or $\square$ other, namely

Battery charging station

Other, namely

\subsection{Technical data}

Please fill in separate boxes for the three (or less) main types of systems used or sold:

\begin{tabular}{|c|c|c|c|c|c|c|}
\hline Voltage of system 1 & $12 \mathrm{~V} \mathrm{DC}$ & $\square$ & $110 / 220 \mathrm{~V} \mathrm{AC}$ & ㅁ & other, namely: & ㅁ \\
\hline \multirow[t]{2}{*}{ Total size of system 1} & Panels & \multicolumn{3}{|r|}{$\mathrm{Wp}$} & & \\
\hline & batteries & \multirow{2}{*}{\multicolumn{3}{|c|}{$\mathrm{Ah}$}} & & \\
\hline \multirow[t]{7}{*}{ appliances or end-uses } & Appliance & & & & \multicolumn{2}{|l|}{ number } \\
\hline & \multicolumn{4}{|c|}{ Lights } & & \\
\hline & \multicolumn{4}{|c|}{ water pump } & & \\
\hline & \multicolumn{4}{|c|}{ radio/TV } & & \\
\hline & \multicolumn{4}{|c|}{ refrigerator } & & \\
\hline & \multicolumn{4}{|c|}{ other appliances namely: } & & \\
\hline & \multicolumn{4}{|c|}{ other appliances namely: } & & \\
\hline $\begin{array}{l}\text { Total cost of system } \mathbf{1} \\
\text { incl. appliances \& installation }\end{array}$ & \multicolumn{6}{|c|}{ Currency: } \\
\hline
\end{tabular}

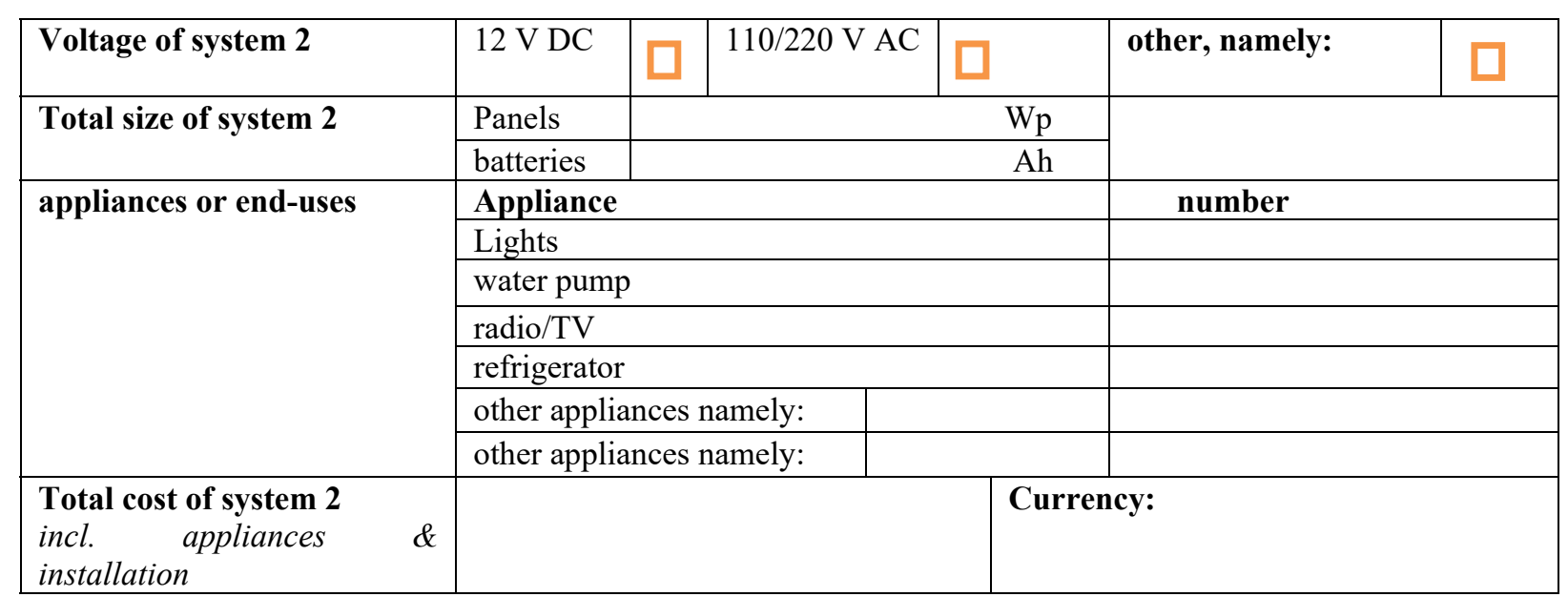




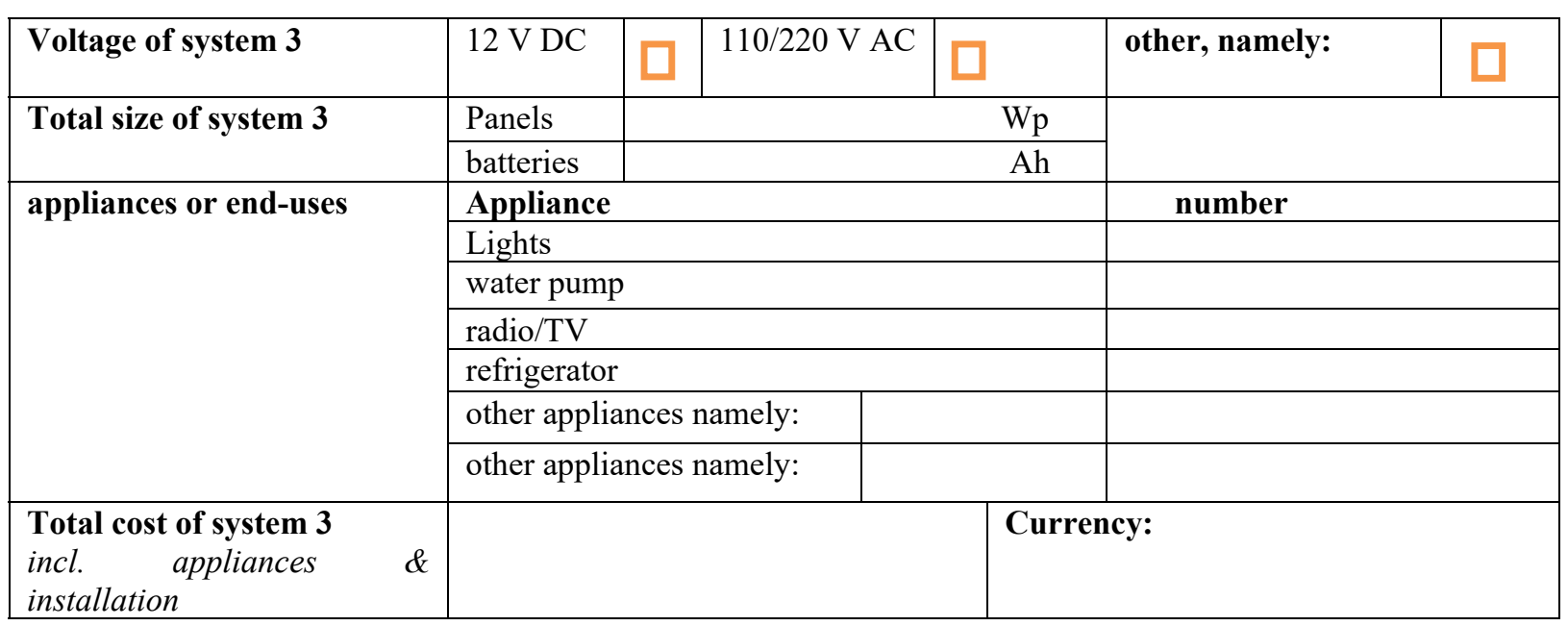

\begin{tabular}{|l|l|}
\hline 1.5. What is the PV-electricity used for? Pls tick box, more than one if appropriate & \\
\hline PV-pumping (irrigation) & \\
\hline PV-pumping (potable water) & \\
\hline PV-Water desalination & \\
\hline Livestock watering & \\
\hline PV-Electric fences & \\
\hline Lighting of Poultry /Livestock & \\
\hline Office equipment (computers, etc.) & \\
\hline Radio or cellular phone communication & \\
\hline Health center (refrigeration, lighting, etc.) & \\
\hline Veterinary service (refrigeration, lighting, etc., & \\
\hline Refrigeration (household, retail store, agricultural products, meat, dairy, fish, etc.) & \\
\hline Lighting, TV, radio, small appliances for commercial services (retail shop/cafe/restaurant) & \\
\hline Lighting, small power tools for micro-enterprises (repair shop, handicraft) & \\
\hline Lighting, TV, radio, etc. for household use & \\
\hline Tourist facilities (lighting, TV, refrigeration of lodges, hotels, etc.) & \\
\hline Lighting and audiovisuals for schools and other community buildings & \\
\hline Street lighting & \\
\hline Other, namely: & \\
\hline Other, namely: & \\
\hline
\end{tabular}

1.6. In your opinion have the PV-systems led to an impact on: please check box (es) and if applicable proceed to indicated questions

\begin{tabular}{|l|l|l|}
\hline Impact on & Check box & \\
\hline $\begin{array}{l}\text { Agricultural/livestock productivity } \\
\text { sural \& cottage industry and commercial } \\
\text { / small business development }\end{array}$ & & please fill in questions 2.1 - 2.4 \\
\hline $\begin{array}{l}\text { Social services and community development } \\
\text { (community level) }\end{array}$ & & please fill in questions 4.1 - 4.5 \\
\hline Household quality of life & & please fill in questions 5.1 - 5.3 \\
\hline $\begin{array}{l}\text { Other (productive) activities } \\
\text { please specify/describe }\end{array}$ & & namely: \\
\hline
\end{tabular}


1.7. How would you characterize the main beneficiaries/users of the PV-systems?

Please check more than 1 box if necessary

\begin{tabular}{|l|l|}
\hline Profession/activity & check \\
\hline small subsistence farmer / rancher / fisherman & \\
\hline commercial farmer / rancher / fisherman & \\
\hline Professional (teacher, nurse, etc.) & \\
\hline landless laborer & \\
\hline self-employed & \\
\hline artisan/craftsman & \\
\hline small family business/shop/trade & \\
\hline larger business/shop/trade > 10 employees & \\
\hline Other, namely: & \\
\hline
\end{tabular}

2. Agricultural \& livestock productivity

2.1. What kind of agricultural/livestock activities has/have been stimulated by the introduction of PV electricity?

Irrigation

refrigeration of crops/meat/fish/dairy/other:

lighting (poultry, livestock)

water pumping for fish farming

water pumping for cattle drinking

pest control

electric fencing for grazing management

Other, namely:

\begin{tabular}{|l|l|}
\hline $\begin{array}{l}\text { 2.2. What beneficial impact(s) did the systems have? } \\
\text { please check box(es), more than one if necessary or fill in last row if choice impact not mentioned }\end{array}$ \\
\hline higher productivity (higher yield) & \\
\hline more land to be cropped & \\
\hline multiple crops per year & \\
\hline new, more marketable product & \\
\hline more animals can be raised & \\
\hline lower losses (death rate) or faster production & \\
\hline better quality product (higher prices/more sales) & \\
\hline access to more profitable markets (e.g. through conservation of product for transport) & \\
\hline better natural resource management & \\
\hline Other, namely: & \\
\hline
\end{tabular}

\subsection{Could you quantify these benefits?}

If possible please describe quantitatively the impact indicated above, e.g. how much more income was earned or how much crops were produced/sold, etc. If necessary include additional material.

\subsection{Were there other positive or negative impacts?}

If desired, please, describe any impacts not yet covered or that need further explanation. 
3. Rural \& cottage industry and commercial services

\begin{tabular}{|l|l|}
\hline $\begin{array}{l}\text { 3.1. What type of business has/have been created, stimulated or improved by the introduction of PV } \\
\text { electricity? check box(es), more than one if necessary or fill in last row if choice business not mentioned }\end{array}$ \\
\hline retail shops / restaurant / bar & \\
\hline rural cinema (TV/video-business) & \\
\hline battery charging & \\
\hline telecommunication shop (mobile phone shop) & \\
\hline repair/technical shop & \\
\hline handicrafts / sewing workshop & \\
\hline tourism (hotel, lodge) & \\
\hline $\begin{array}{l}\text { other business/productive } \\
\text { activity, namely: }\end{array}$ & \\
\hline
\end{tabular}

\begin{tabular}{|l|l|}
\hline $\begin{array}{l}\text { 3.2. What beneficial impact(s) did the systems have? } \\
\text { check box(es), more than one if necessary or fill in last row if choice impact not mentioned }\end{array}$ & \\
\hline longer working hours / longer opening times & \\
\hline $\begin{array}{l}\text { new business opportunity through use of new equipment (power tools, phone, etc.) or new, more } \\
\text { marketable product (e.g. handicrafts) }\end{array}$ & \\
\hline higher productivity & \\
\hline better quality product (higher price) & \\
\hline more sales & \\
\hline better quality service (e.g. more attractive business through provision of light, music, cold drinks, etc.) & \\
\hline creation of home/cottage industry & \\
\hline more employment & \\
\hline Other, namely: & \\
\hline
\end{tabular}

\subsection{Could you quantify these benefits?}

If possible please describe quantitatively how much more business/product sold, more production, higher price, more man hours worked, etc. If necessary include additional material.

\subsection{Were there other positive or negative impacts?}

If desired please describe any impacts not yet covered or that need further explanation

4. Social services and community development (community level)

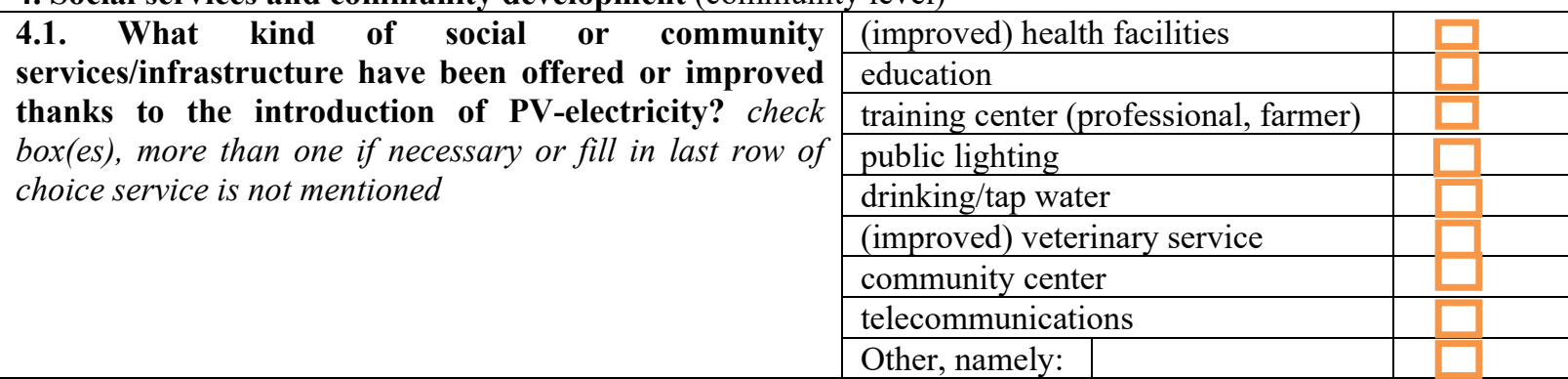

4.2. In what way has local lifestyle improved because of the introduction of PV electricity? check box(es), more than one if impact not mentioned necessary or fill in last row if choice

\begin{tabular}{l} 
better quality courses/training \\
$\begin{array}{l}\text { More involvement and participation in community } \\
\text { development activities }\end{array}$ \\
\hline productive activities / handicrafts (in the evening) \\
courses/classes/training or homework in the evening \\
\hline better opening hours shops, restaurants, etc. \\
\hline $\begin{array}{l}\text { liberating time of villager for other activities, especially for } \\
\text { women }\end{array}$ \\
\hline better communications and/or information \\
\hline improvement of local natural environment \\
\hline higher health standards \\
\hline Other, namely:
\end{tabular}




\subsection{Could you quantify these benefits?}

If possible please describe impact quantitatively, e.g. estimated no. of people helped, \% less incidence of disease, working hours per week saved, etc. If necessary include additional material. If necessary include additional material.

\subsection{Were there other positive or negative impacts?}

If desire please describe any impacts not yet covered or that need further explanation.

5. Household quality of life improvement

\subsection{What is the PV-electricity mainly used for?}

check box(es), more than one if necessary or fill in last row if choice end-use not mentioned

lighting

TV/radio

refrigeration

Other, namely:

5.2. What principal improvements have taken place in the households that now have access to PVelectricity? check box(es), more than one if necessary or fill in last row if choice impact not mentioned work / education / homework in the evening

better recreation possibilities (TV/radio, reading, etc.)

better health conditions (refrigeration, no smoke, no danger of fire)

time liberation, especially for women

more pride/self-esteem/positivism

improvements in housing coinciding with installation

Other, namely:

\subsection{Were there other positive or negative impacts?}

If desired please describe any impacts not yet covered or that need further explanation

\section{Selection, finance and installation}

6.1. Were any nationally manufactured components used in the PVsystems? If yes, could you estimate the value of the nationally manufactured components as \% of the total costs of the PV-system (including appliances and installation)?

6.2. Was any local/national labor used during installation?

If yes, could you estimate the value of local/national labor as \% of the total costs of the PV-system (including appliances and installation)?

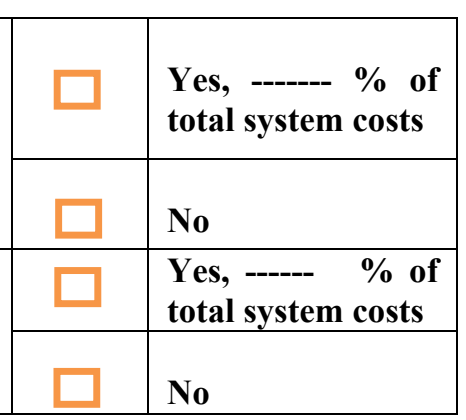

\begin{tabular}{|l|l|}
\hline 6.3. How the PV-systems (mainly) were financed? pls tick appropriate box and fill details if necessary \\
\hline $\mathbf{1 0 0} \%$ customer paid (cash) & \\
\hline $\mathbf{1 0 0 \%}$ customer paid (credit) \\
Interest rate (\%) -------\%, Down-payment (\%) ------\%, period of payment (years) ---- years & \\
\hline Leasing / fee for service & \\
\hline Grant/gift & $\square$ \\
\hline Mix grant: ------ \%, cash: ---- \%; credit -------- \%; leasing -------- \% & $\square$ \\
\hline Other, namely: $\quad \square$ \\
\hline
\end{tabular}

6.4. Has another energy technology been considered for the same use? Yes, $\square$ generator $\square$ wind $\square$ grid extension; $\square$ other, namely: No 
6.5. Why was $P V$ chosen in this case?

Please specify.

6.6. Was a cost comparison done with other technical options?.

Yes $\square$, please specify costs of compared technical options

No

6.7. Was a cost-benefit analysis done for the PV-project?

Please specify.

Yes $\square$, please specify

No

7. Impact improvement / potential of PV

7.1. In your opinion, how could the impact of projects using PV-electricity is improved?

Please describe ways to improve impact. e.g. concerning intensity of impact, type of PV-projects, diffusion to wider target group, cost-benefit

7.2. In your opinion, what is the potential of PV for Rural Development?

If possible please describe.

7.3. If you have any additional commentaries on the questionnaire or others, that could not be covered in earlier questions, please describe here: 